\title{
A new bisporangiate lycopsid cone genus Thomasostrobus gen. nov. from the Late Pennsylvanian of the Intra-Sudetic Basin (Czech Republic)
}

\author{
STANISLAV OPLUŠTIL, JIŘí BEK \& JANA DRÁBKOVÁ
}

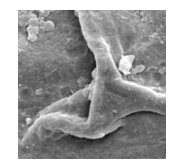

\begin{abstract}
A new bisporangiate lycopsid cone genus Thomasostrobus gen. nov. from the Stephanian strata of the Intra-Sudetic Ba$\sin$ (Czech Republic) is proposed as a new organ genus. The only species in the genus, Thomasostrobus longus sp. nov., is established. Mega- and microsporangia are arranged in zones, with megasporangia in the lower part of the cones and microsporangia in their apical portions. Microspores assigned to the dispersed genus Cadiospora and megaspores comparable with the dispersed species Sublagenicula levis, are described in situ for the first time. The possible parent plant of Thomasostrobus longus is discussed and an overview of dispersed Cadiospora and Sublagenicula spores is given. Key words: lycopsids, in situ spores, Cadiospora, Sublagenicula, Pennsylvanian.
\end{abstract}

\begin{abstract}
OPLUŠTIL, S., BEK, J. \& DRÁBKOVÁ, J. 2009. A new bisporangiate lycopsid cone genus Thomasostrobus gen. nov. from the Late Pennsylvanian of the Intra-Sudetic Basin (Czech Republic). Bulletin of Geosciences 84(2), 283-300 (8 figures, 5 tables). Czech Geological Survey, Prague. ISSN 1214-1119. Manuscript received February 27, 2009; accepted in revised form May 7, 2009; published online May 27, 2009; issued June 30, 2009.

Stanislav Opluštil, Faculty of Sciences, Charles University, Albertov 6, 12843 Prague 1, Czech Republic; oplustil@natur.cuni.cz・Jiři Bek, Department of Palaeobiology and Palaeoecology, Institute of Geology v.v.i., Academy of Sciences, Rozvojová 269, 16500 Prague 6, Czech Republic; bek@gli.cas.cz•Jana Drábková, Czech Geological Survey, Klárov 3, 11821 Prague 1, Czech Republic; jana.drabkova@ geology.cz
\end{abstract}

Lycopsid strobili, either isolated or, rarely, in organic connection with their parent plants, are common plant fossils in the Pennsylvanian strata. The first lycopsid cone was described by Brongniart (1828) as Lepidostrobus ornatus Brongniart. Since that time, several other lycopsid genera and numerous species have been established. Their determination has primarily been based only on the cone morphology; however such an approach frequently resulted in misinterpretation. This was confirmed when several isolated specimens assigned to the same species provided different spores, or when similar cones were found in organic connection with different types of leafy shoots (Bek \& Opluštil 2004, 2006). This proved that general morphology is often insufficient for precise determination of isolated cones especially in compression specimens. Consequently, the use of additional characteristics such as in situ spores and leafy shoots has been shown to be necessary. A connection between a cone with leafy shoots from the parent plant is, however, quite rare, and some cone species have never been found with such a connection. On the other hand, in situ spores are often successfully released from lycopsid strobilus, thus providing a very helpful tool for more precise identification of isolated cones. Therefore, in situ spores often serve as one of the main criteria used for generic classification of lycopsid cones (Brack-Hanes \& Thomas 1983), and their description is now accepted as an important part of their diagnoses (Chaloner 1953; Thomas \& Dytko 1980; Brack-Hanes \& Thomas 1983; Bek \& Opluštil 2004, 2006). Based on spore content, cone morphology and/or anatomy, and type of parent plant, several cone genera born by the tree lycopsids Lepidodendron Sternberg, Lepidofloyos Sternberg, Synchysidendron DiMichele \& Bateman, Diaphorodendron DiMichele, Paralycopodites Morey \& Morey emend. DiMichele \& Willard, Bothrodendron Lindley \& Hutton and Sigillaria Brongniart, were established.

Until now, only a few bisporangiate Carboniferous arborescent lycopsid cone genera were recognised: Flemingites (Carruthers) Brack-Hanes \& Thomas and Moscvostrobus Naugolnykh \& Orlova. The former was born on the lepidodendrid lycopsid Paralycopodites (Bateman et al. 1992, DiMichele \& Bateman 1996). This cone genus bears Lycospora orbicula-type microspores and Lagenicula or Lagenoisporites-type megaspores (Brack-Hanes \& Thomas 1983). Moscvostrobus, described from the only specimen of an isolated cone from the Late Mississippian of the Moscow Basin, represents a large spherical bisporangiate strobili bearing Lycospora orbicula-type 
microspores and Sublagenicula-type megaspores (Naugolnykh \& Orlova 2006). Cones of the remaining genera were either microsporangiate (male) or megasporangiate (female) or are rather interpreted as fertile zones or apex [(e.g., Omphalophloios (White) Brousmiche-Delcambre et al.]. No other types of arborescent bisporangiate lycopsid strobili had been known until recently when such forms were identified among specimens from the Intra-Sudetic Basin in the Czech Republic. Although its general morphology can resemble some Flemingites cones, it yielded completely different in situ spores; microspores are assigned to the dispersed genus Cadiospora Kosanke whereas megaspores are compared with the dispersed species Sublagenicula levis (Zerndt) Dybová-Jachowicz et al. and both of them are described as in situ for the first time. Therefore this cone must be proposed as a new organ genus.

\section{Material and methods}

The studied material involves three specimens (Z ̌́ 307a, b; E 6353a, b; E 6354a, b) from the Radvanice coal group (Stephanian B) of the Intra-Sudetic Basin, Czech Republic. All the specimens were collected from the dump of the Kateřina (formerly Stachanov) coal mine during its operation in the 1980s. Specimens ZS $307 \mathrm{a}, \mathrm{b}$ are stored in the collections of the Czech Geological Survey, Prague, and specimens E 6353a, b and E 6354a, b are in the collections of the National Museum in Prague, Czech Republic. Photomicrographs of micro- and megaspores and slides with microspores are stored in the Czech Geological Survey and Department of Palaeobiology and Palaeoecology, Institute of Geology, Academy of Sciences, Prague, Czech Republic. Megaspores used for SEM are stored in the Czech Geological Survey, Prague, Czech Republic.

Morphology of the cones is combined with a description of spores released from various parts of the strobili (basal, middle and apical). Micro- and megaspores were recovered by dissolving small portions of cones (separated from the cone specimens with a mounted needle) in nitric acid for 24-48 hours and $\mathrm{KOH}$ for 1-2 hours. Most microspores were mounted in glycerine jelly for direct microscopic examination. Some mega- and microspores were sputter-coated with gold for examination with a CAMECA
SX100 scanning electron microscope. Descriptive terms for the spores follow the latest edition of the Glossary of Pollen and Spore Terminology (Punt et al. 2007). Spores are classified according to the system of dispersed spores suggested by Potonié \& Kremp (1954, 1955), Dettmann (1963), and Smith \& Butterworth (1967). In situ spores were compared directly with the original diagnoses (type specimens), descriptions and illustrations of dispersed spore species. Species determinations are based only on the original diagnoses, and not on the interpretations of subsequent authors.

\section{Systematic part}

Class Lycopsida Scott, 1909

Order Lepidocarpales Thomas \& Brack-Hanes, 1984

\section{Genus Thomasostrobus gen. nov.}

Type species. - Thomasostrobus longus sp. nov.

Derivation of name. - In honour of Prof. Barry A. Thomas, from the University of Aberystwyth, Wales, UK, excellent palaeobotanist and friend.

Diagnosis. - Bisporangiate cylindrical lycopsid strobili with lower megasporangiate and upper microsporangiate parts. Sporophylls arranged in low angle spirals. Sporangia oval, attached to adaxial surface of sporophyll pedicel along its length. Abaxial keel along length of pedicel. Microspores laevigate trilete with circular to subcircular amb and prominent labrum. Oval to circular trilete megaspores with subgula. Prominent triradiate tecta and contact area delimited on the distal surface by distinct curved ridges. Triradiate ridges and part of the contact area elevated near the apex, creating regular pyramidal triangular subgula.

Comparison. - Thomasostrobus is comparable to the genera Flemingites, Moscvostrobus and Sigillariostrobus. Thomasostrobus and Flemingites represent morphologically similar narrow cylindrical cones with sporophylls attached to the cone axis in low angle spirals. Both genera are also bisporangiate, with megasporangiate and microspo-

Figure 1. A - Thomasostrobus longus sp. nov. Specimen No. ZS 307 a bears remains of six strobili preserved in a dark grey slab of "roof shale". "H" indicates cone selected as the holotype. Kateřina (formerly Stachanov) Mine in Radvanice near Trutnov, NE Bohemia, Radvanice group of coals, Stephanian B, Intra-Sudetic Basin. Megasporangiate and microsporangiate parts of cones indicated. Arrows point to the boundary between megasporangiate and microsporangiate parts of cones. Photographed in polarised light. Scale bar $20 \mathrm{~mm}, \times 0.85$. $\bullet$ B - in situ microspores isolated from Thomasostrobus longus sp. nov. (ZŠ 307a) and compared to the dispersed spore species Cadiospora magna Kosanke. Notice prominent elevated rays of trilete mark on the proximal surface (upper microspore specimen) and laevigate sculpture on the distal surface (lower microspore specimen). SEM. Scale bar $20 \mu \mathrm{m}$. $・ \mathrm{C}$ - in situ microspore isolated from Thomasostrobus longus sp. nov. (ZŠ 307a) and compared to the dispersed spore species Cadiospora magna Kosanke. Notice prominent elevated rays of trilete mark on laevigate proximal surface. SEM. Scale bar $20 \mu \mathrm{m}$. $\bullet$ D-F - in situ microspores isolated from Thomasostrobus longus sp. nov. (ZŠ 307a) and compared to the dispersed spore species Cadiospora magna Kosanke. All $\times 500$. 

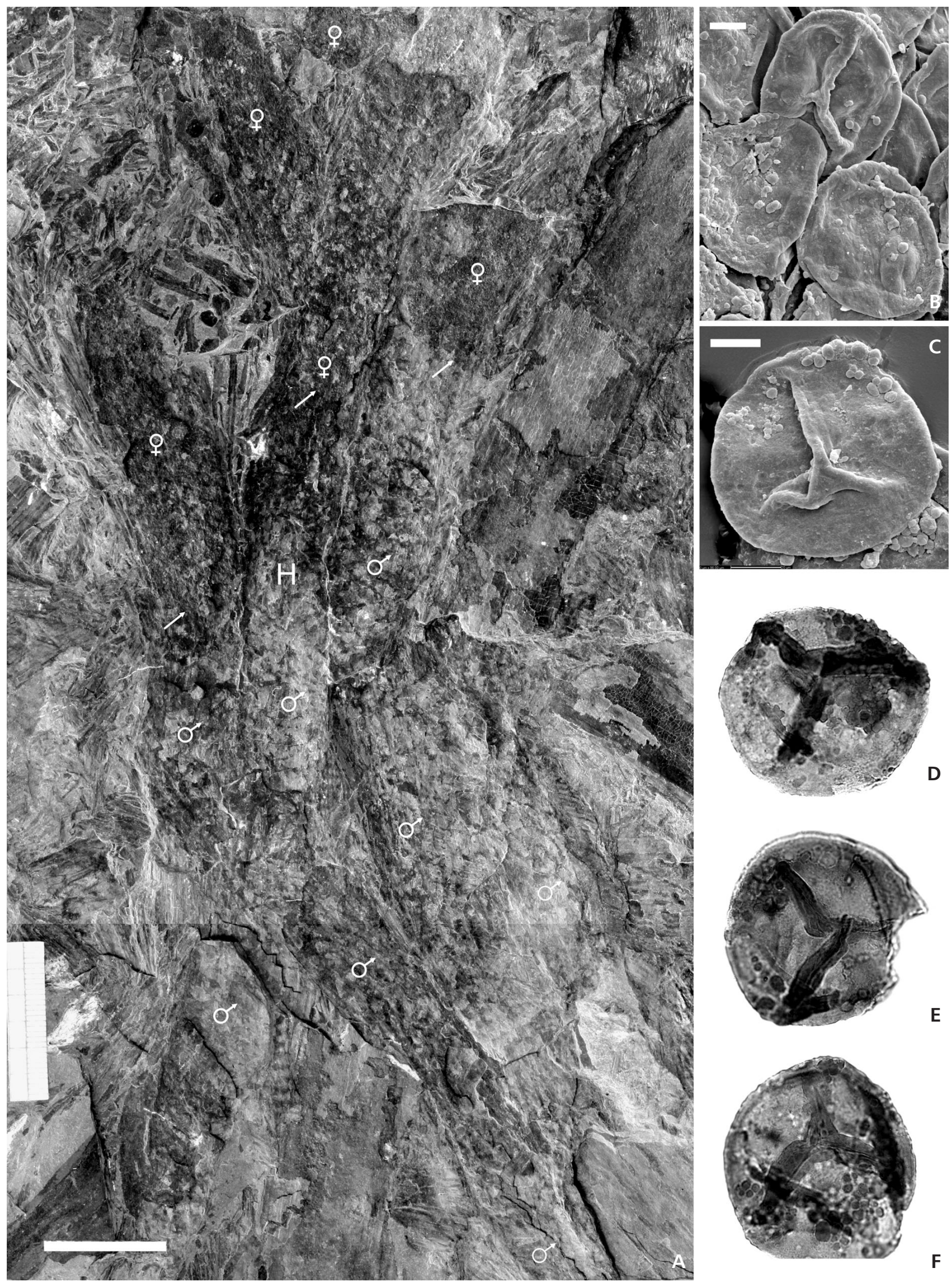
rangiate parts. Their in situ spores are, however, different. Thomasostrobus produced Cadiospora microspores and Sublagenicula megaspores, whereas Flemingites cones contain microspores of the Lycospora orbicula-type and megaspores of the Lagenoisporites or Lagenicula-types.

The genus Moscvostrobus from the Late Mississippian (Serpukhovian) of the Moscow Basin is similar to Thomasostrobus only in its bisporangiate character and in having the same type of megaspores, i.e. Sublagenicula-type. Its microspores are, however, Lycospora orbicula-type and therefore do not correspond with those of Thomasostrobus. Also the cone morphology is quite different; Moscvostrobus strobili are large and spherical whereas those of Thomasostrobus are cylindrical.

The genera Thomasostrobus and Sigillariostrobus are similar in cone morphology but they clearly differ completely in being bisporangiate or monosporangiate, respectively, and in the type of in situ spores. Female strobili of Sigillariostrobus bear megaspores of the genera Tuberculatisporites Ibrahim or Laevigatisporites (Ibrahim) Potonié \& Kremp and male cones contain only microspores of the Crassispora-type which differ from those of Thomasostrobus cones. Both cone genera, however, are represented by narrow cylindrical cones with sporophylls arranged in low angle spirals. The laminae of Sigillariostrobus cones usually have ciliate margins. Based on the available study material, it is also impossible to recognise if Thomasostrobus represents a pedunculate type of cone, thus displaying further similarity to the genus Sigillariostrobus.

Remarks. - Erection of the new genus Thomasostrobus is based mainly on its bisporangiate nature and character of its in situ spores, which are quite different from the spores of any other bisporangiate lycopsid strobili. Thus the spore content provides the most reliable way to determine this genus.

\section{Thomasostrobus longus sp. nov.}

Figures 1A, 2-4

Holotype. - Cone indicated as "H" on specimen ZŠ 307a, b (part and counterpart) stored in the collections of the Czech Geological Survey, Prague, Czech Republic.

Type locality. - Kateřina (formerly Stachanov) Mine in Radvanice near Trutnov, NE Bohemia, Intra-Sudetic Basin.

Type horizon. - Radvanice group of coals (Stephanian B, Late Pennsylvanian), Jívka Member, Odolov Formation.

Derivation of name. - According to the apparent length of this cone species.
Material: The studied material involves three specimens (ZŠ 307a, b; E 6353a, b; E 6354a, b), including the type specimen (ZŠ $307 \mathrm{a}, \mathrm{b}$, which is part and counterpart). The specimens come from the Kateřina Mine in Radvanice and are preserved in shale as compressions or impressions. Specimen ZS $307 \mathrm{a}, \mathrm{b}$ is stored in the collections of the Czech Geological Survey, Prague, and specimens E 6353a, $\mathrm{b}$ and E 6354a, b are in the collections of the National Museum in Prague, Czech Republic.

Diagnosis. - Bisporangiate cylindrical strobili, more than $230 \mathrm{~mm}$ long, 18-20 mm wide without distal laminae and 24-26 mm wide including them, with lower megasporangiate and upper microsporangiate parts. Axis $4 \mathrm{~mm}$ in diameter. Pedicels triangular, 6-7 mm long, in low spirals perpendicular to the cone axis, distal laminae triangular with straight entire margins, 17-22 $\mathrm{mm}$ long and $3 \mathrm{~mm}$ wide at the base. Sporangia oval, about 5.5-6.5 $\mathrm{mm}$ long and $2 \mathrm{~mm}$ wide. Trilete circular to subcircular microspores. Exine of both surfaces laevigate. Rays of trilete mark with prominent labrum. Circular tectate megaspores with subgula. Triradiate ridges and part of the contact area are elevated near the apex and create a regular pyramidal triangular subgula. The sculpture of the three-layered exine is laevigate and punctate.

Description of cones. - The holotype is a cone preserved in a slab of grey thinly bedded mudstone from the roof of the coal seam. This slab contains the remains of at least six incomplete, long, narrow cones of comparable size and morphology of which the one indicated by " $\mathrm{H}$ " is selected here as the holotype (Fig. 1A). The most complete fragment is $240 \mathrm{~mm}$ long, however, neither base nor apex is preserved on any cone. The width is more or less constant along the entire preserved length, and varies between 18 and $20 \mathrm{~mm}$ without distal laminae and between 24 and $26 \mathrm{~mm}$ including distal laminae that are adpressed to the cone body. Megasporangiate and microsporangiate zones are clearly distinct (Fig. 2), and the boundary between them is abrupt. The megasporangiate zone occupies approximately the basal third of the preserved cone, whereas the remaining upper two-thirds represents the microsporangiate part. The megasporangiate zone of the most complete specimen is $90 \mathrm{~mm}$ long and the longest preserved microsporangiate zone measures $170 \mathrm{~mm}$ long. Cones are split mostly along the surface or, in the case of megasporangiate parts, along the megasporangia surfaces. However, individual sporangia are not distinguishable, probably due to the partial disintegration of the cone prior to fossilisation. Instead, masses of megaspores can be seen with the naked eye to cover the cone surface (Figs 2A, C-E, 3D, E). Locally, they are grouped into oval bodies that probably represent the outline of former sporangia (Fig. 2A). Laminae are not clearly seen on the holotype. Where measurable, they are narrow, triangular with entire margins, 17-22 $\mathrm{mm}$ long and $3 \mathrm{~mm}$ 

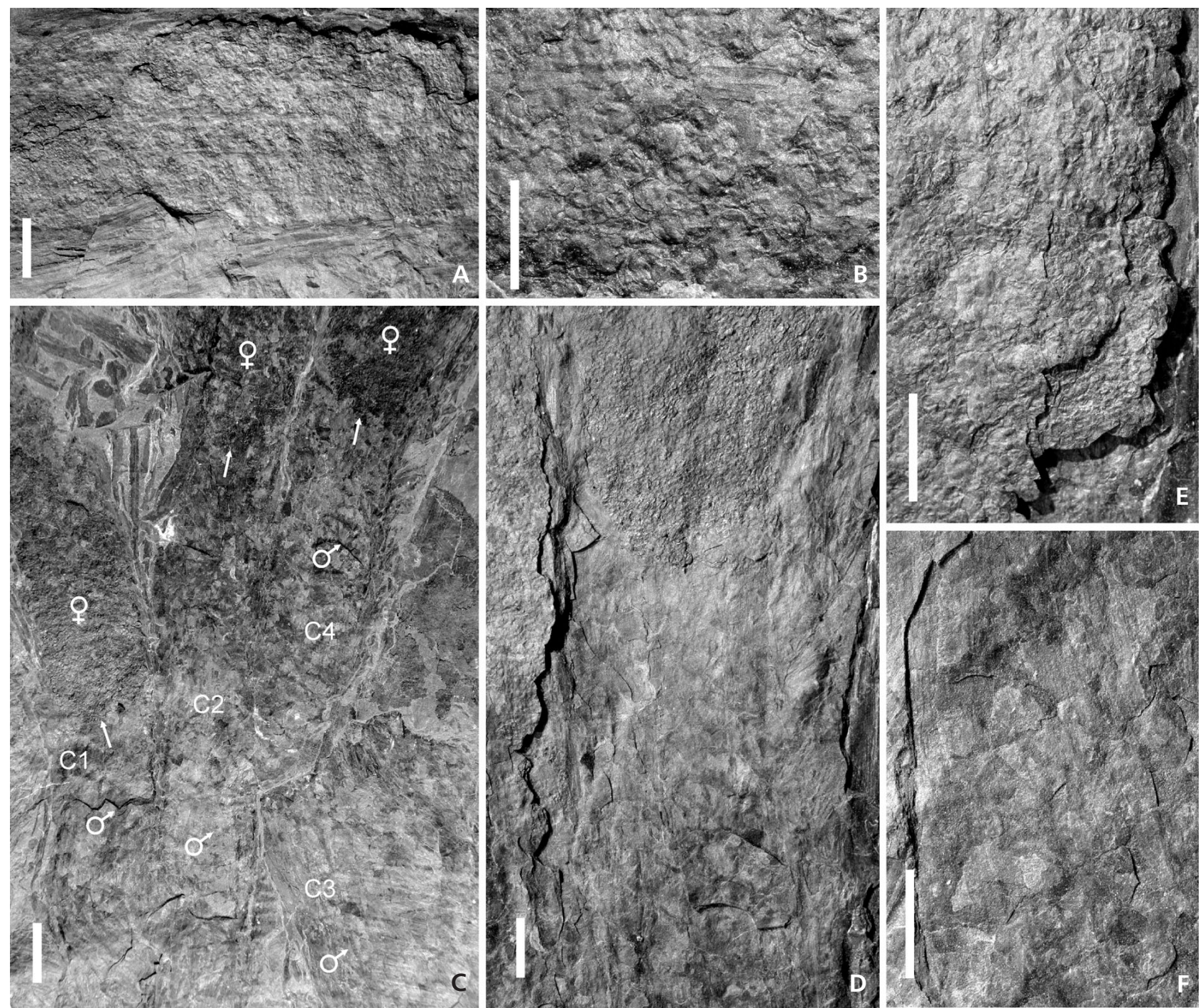

Figure 2. A-detail of megasporangiate part of the cone $\mathrm{C} 1$. Scale bar $5 \mathrm{~mm}, \times 2$. $\bullet \mathrm{B}-$ megaspores of the cone $\mathrm{C} 1$. Detail of Fig. $2 \mathrm{~A}$. Scale bar $3 \mathrm{~mm}, \times 6$. - C - Thomasostrobus longus sp. nov. Detail of the central part of cones from the holotype. Note the contact between megasporangiate (right) and microsporangiate (left) parts of strobili. Czech Geological Survey, Prague (Specimen No ZŠ 307a). C1-C4 indicates particular cones. Megasporangiate and microsporangiate parts of cones indicated. Arrows point to the boundary between megasporangiate and microsporangiate parts of cones. Scale bar $10 \mathrm{~mm}, \times 1$. $\bullet \mathrm{D}$ - detail of the contact between megasporangiate and microsporangiate parts of the cone C4. Scale bar $5 \mathrm{~mm}, \times 2$. $\bullet-\mathrm{E}-\mathrm{detail}$ of megasporangiate part of the cone C1. Scale bar $6 \mathrm{~mm}, \times 3$. $\bullet \mathrm{F}-$ detail of microsporangiate part of the cone C4. Scale bar $6 \mathrm{~mm}, \times 3$.

wide at the base. Very fine striations parallel to the laminar margins can be sometimes observed under the binocular microscope (Fig. 2F). They most probably represent sclerenchymatic thickenings. Axes typically are seen only as outlines overprinted by the cone surface, although two, 1-2 cm long, cone fragments are split along the $4 \mathrm{~mm}$ wide axes. Small scars arranged as low angle spirals cover the axis surface. The distance between neighbouring spirals varies between 2.5 and $2.7 \mathrm{~mm}$.

Another Czech specimen (E 6354a, b) is a $230 \mathrm{~mm}$ long fragment of a cylindrical strobilus missing its base (Fig. 3). The apex is gently pointed (Fig. 3B). The cone is split along the surface so the axis can be seen along the entire length. It is $4 \mathrm{~mm}$ thick except in the apical part where it thins to $3.2 \mathrm{~mm}$ (Fig. 3B, C). Small leaf scars are typically arranged in slightly ascending (up to about $25^{\circ}$ ) spirals (Fig. 3A-C, F). Neighbouring verticils are $2.5 \mathrm{~mm}$ apart. There are 3-4 leaf scars in each of them. Pedicels are not clearly visible, however, they are perpendicular to the cone axis except in the apical part of the cone where they are attached, slightly down pointing, at an angle of 20 to $30^{\circ}$ (Fig. 3B, C). They are 6-7 mm long. Laminae preserved along the cone margins are adpressed to the cone body and bend gently toward the cone tip. Middle and lower parts of this specimen provided megaspores of the Sublagenicula-type, whereas Cadiospora magna microspores were 
released from an area about $40 \mathrm{~mm}$ below the apex. The boundary between mega- and microsporangiate zones is not clearly distinct in this specimen.

The remaining specimen E 6353 from the same locality as the holotype represents an $80 \mathrm{~mm}$ long fragment of the central part of a cylindrical cone split along the surface (Fig. 4). The cone is $23-25 \mathrm{~mm}$ wide including the laminae. Its axis is identical with that of the previous specimen (E 6354). The shape and size of sporophylls are also identical. Pedicels are triangular both from a lateral and horizontal view. They are approximately $6 \mathrm{~mm}$ long, with a keel along the abaxial margin that is terminated at its distal end by a heel. Here the pedicels are about $2 \mathrm{~mm}$ high and $2 \mathrm{~mm}$ wide. Sporangia are oval, adaxially attached and filling most of the space between neighbouring pedicels. Pedicels are attached perpendicularly, although in the basal part of the cone fragment they are turned downward (Fig. 4A, B, D). This specimen provided both Sublagenicula megaspores and Cadiospora microspores. Megaspores were released from the lower half of the cone fragment, whereas microspores were recovered from a sample taken from the upper part.

Description of spores. - Microspores prepared from the holotype are all morphologically very similar, except for a slightly variable diameter. They are circular to subcircular trilete and 89 (101) $113 \mu \mathrm{m}$ in diameter. The laevigate exine is $3-4 \mu \mathrm{m}$ thick. Rays of the trilete mark reach two-thirds to three-quarters of the radius (Fig. 1B-F). The labrum is 8 (10.7) $12 \mu \mathrm{m}$ wide and high. Microspores can be assigned to the dispersed genus Cadiospora and are comparable with the species Cadiospora magna.

Megaspores are triradiate tectate with subgula (i.e. morphological type of gula formed of tecta which are raised and/or thickened from the middle part of the tectum to the sharp apex, Dybová-Jachowicz et al. 1979). They are 633 (828) $1012 \mu \mathrm{m}$ long along the polar axis and 600 (710) $866 \mu \mathrm{m}$ wide. More than $90 \%$ of the megaspores are preserved as lateral compressions (Fig. 5). The lateral shape is roughly oval to broadly circular with a subtriangular subgula shape at the apex. The equatorial shape is circular to broadly circular or subtriangular. Triradiate ridges (tectum) are prominent, 404 (471) $557 \mu \mathrm{m}$ long, and $30 \mu \mathrm{m}$ wide and high. The tectum and a part of the contact area create a pyramidal subgula at the apex (Fig. 5). Haptotypic features consist of prominent triradiate tecta and a relatively large contact area delimited on the distal surface by distinct curved ridges. Contact areas are distinct and relatively large, being delimitated by more or less developed arcuate ridges. Where the tecta meet the arcuate ridges, horn-like extensions of the tecta may be developed. Arcuate ridges are darker, $30 \mu \mathrm{m}$ wide and 10-20 $\mu \mathrm{m}$ high, rounded in profile, and sometimes almost reach the equator. The pyramidal subgula is well developed, 177 (230) $278 \mu \mathrm{m}$ high, $175-215 \mu \mathrm{m}$ wide, and restricted at the base. It possesses three folds. Rays of the trilete mark are 180-250 $\mu \mathrm{m}$ long and often opened (Fig. 5D-F). The exine observed in reflected light seems to be laevigate, faintly glossy with low folds and impressions of the other megaspores in the original tetrads. However, a two- or three-layered, punctate exine can be seen in SEM (Figs 6-8). The outer punctate layer is $10-15 \mu \mathrm{m}$ thick, and its surface is sponge-like. This layer possesses irregular, several short fibres at the base (Figs 6-8). Fibres of sporopollenin are not oriented in any particular direction and are larger inside (length of the fibres is $\leq 1 \mu \mathrm{m}$, their width $\leq 4 \mu \mathrm{m}$ ). The middle exine layer is more condensed (2-3 $\mu \mathrm{m}$ thick), and can be present in the area of the subgula. The third (innermost) exine layer is very thin, laevigate, and glossy. Many ubish bodies and/or their impressions occur on the megaspore surface. The megaspores are comparable to the dispersed species Sublagenicula levis (formerly Lagenicula levis Zerndt). Dispersed Sublagenicula levis megaspores are known from the same locality and stratigraphic level as the holotype of Thomasostrobus longus (Radvanice in the Intra-Sudetic Basin, Radvanice group of coals, Stephanian B). Sublagenicula levis also commonly occur in Stephanian coal seams of central and western Bohemia, i.e., in the Kounov and Mělník coal groups (Table 4).

Kalibová (1951) described and determined similar dispersed megaspores as Triletes nudus (Nowak \& Zerndt) Schopf et al. from the Lubná coal group of the Radnice Member (Bolsovian) in central Bohemia. This author considered Triletes levis (Zerndt) Schopf et al. to be a synonymum of Triletes nudus. Because of the different stratigraphic position of these megaspores, coal from these seams was re-examined by one of the authors (JD) to compare dispersed Triletes nudus megaspores with those recovered from Thomasostrobus. Megaspores obtained from the Lubná coals are laevigate with a subgula of the Sublagenicula nova-type sensu Dybová-Jachowicz et al. (1979). Some of them are comparable in size to megaspores from Thomasostrobus longus; however, their exine is thicker $(45-55 \mu \mathrm{m})$ and glossier. Arcuate ridges are often indistinct and the subgula is not restricted at the base. Megaspores from the Lubná coal group also differ from those of

Figure 3. A - Thomasostrobus longus sp. nov. Specimen E 6354a. National Museum in Prague. Scale bar $10 \mathrm{~mm}, \times 0.9$. $\bullet \mathrm{B}-$ apical part of the specimen from the Fig. 3A. Scale bar $3 \mathrm{~mm}, \times 3$. $\bullet$ C - detail of Fig. 3B. Axis showing imprints of pedicel arranged into low angle spirals. Scale bar 4 mm, $\times 6$. - D - lower central part of the cone with megaspore tetrad. Scale bar $3 \mathrm{~mm}, \times 3 . \bullet \mathrm{E}-$ detail of the megaspore tetrad from Fig. 3D. Scale bar $1 \mathrm{~mm}, \times 9$. - F - basal megasporangiate part of cone fragment of the same specimen. Scale bar $3 \mathrm{~mm}, \times 3$. 


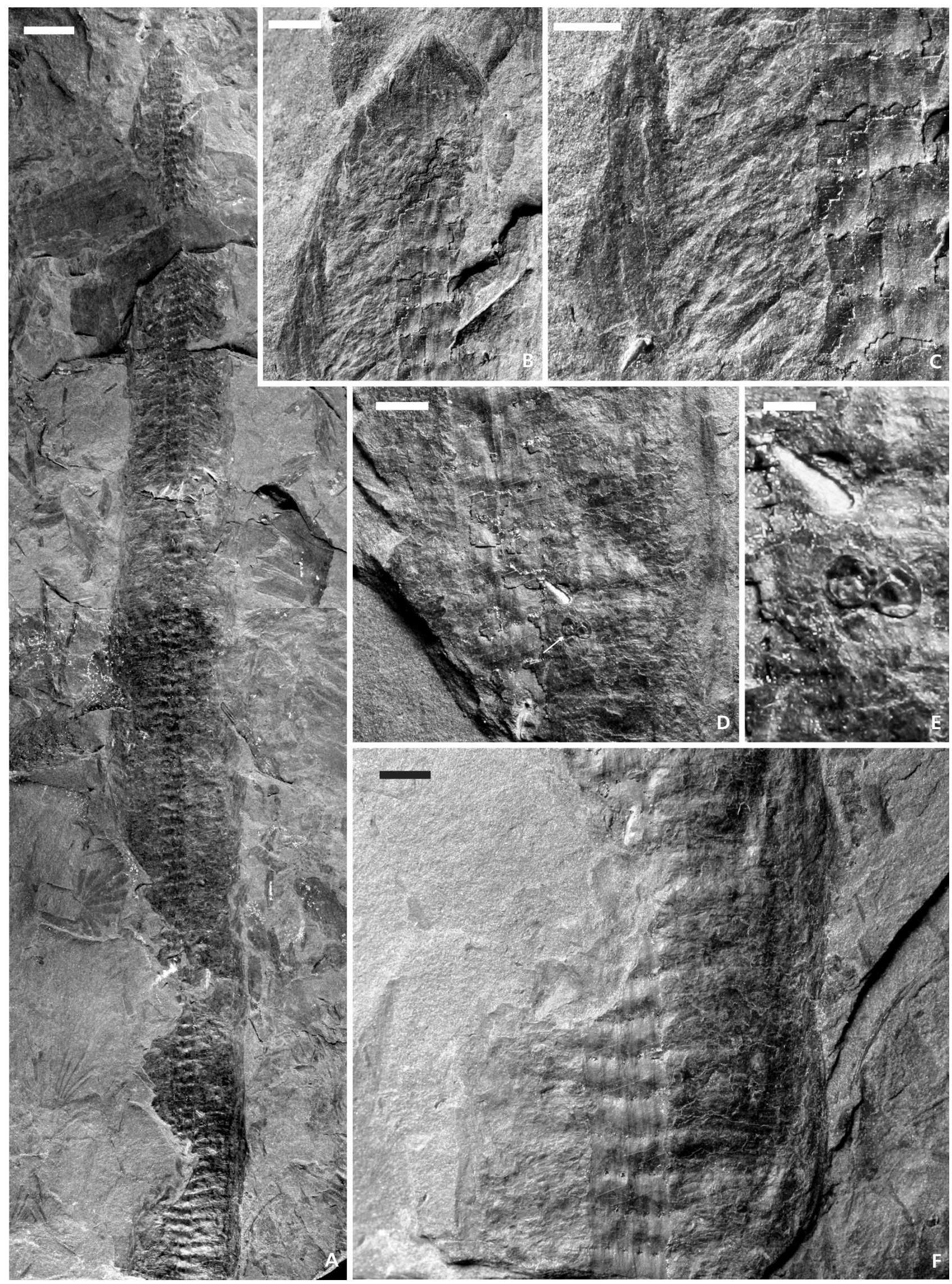



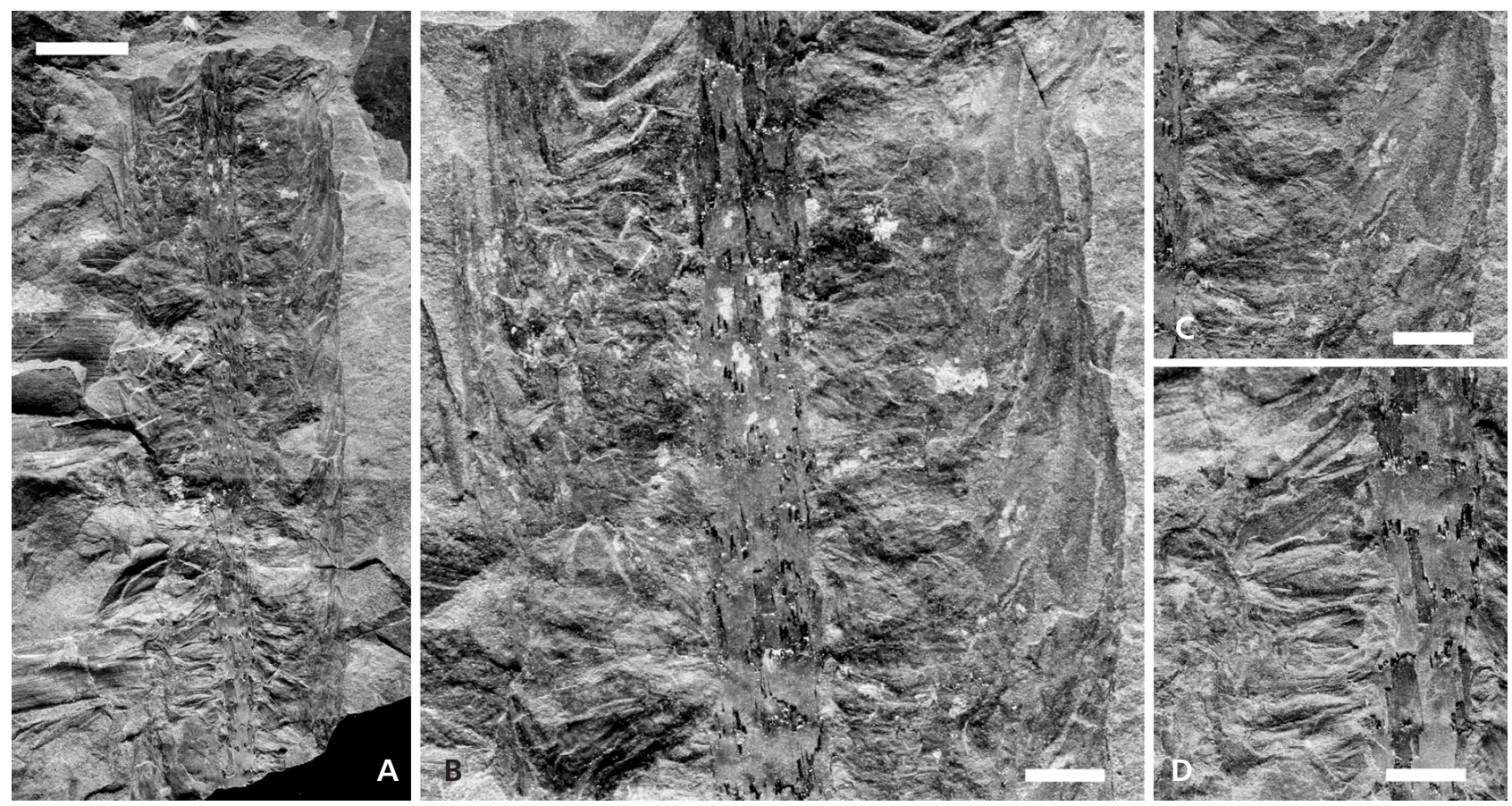

Figure 4. A - Thomasostrobus longus sp. nov. Specimen E 6353a. Natural size. National Museum in Prague. Scale bar $10 \mathrm{~mm}, \times 1$. $\bullet$ B - detail of the axis and sporophylls of the same specimen. Scale bar $3 \mathrm{~mm}, \times 3 . \bullet \mathrm{C}-$ detail of sporophylls with laminae. Scale bar $3 \mathrm{~mm}, \times 3$. $\bullet \mathrm{D}-$ detail of pedicels and axis from basal part of the specimen E 6353. Scale bar $3 \mathrm{~mm}, \times 3$.

Thomasostrobus longus in being more massive. Such megaspores belong to Sublagenicula nuda sensu Dybová-Jachowicz et al. (1979) and were presumably produced by a different parent plant. This is in agreement with the absence of Cadiospora microspores in the Lubná coal group.

Winslow (1959) described the dispersed megaspores Triletes levis (Zerndt) Schopf et al. from Illinois and apparently considered the general shape and dimensions to be identical to those illustrated by Zerndt (1937). She also compared her spores with those described by Dijkstra (1958), who prepared them from the specimens from Kansas that were re-examined above.

Megaspores of the Sublagenicula (Triletes) levis-type are also very similar to the dispersed species Triletes hispanicus Dijkstra described by Dijkstra (1955) from the late Stephanian/early Permian Puertollano Coalfield in Spain. Dybová-Jachowicz et al. (1987) re-examined Dijkstra's original material and assigned his species to Sublagenicula nova (Dijkstra) Dybová-Jachowicz et al. However, we interpret Triletes hispanicus as Sublagenicula levis, which indicates that the parent plant of Thomasostrobus longus occurred in this coalfield. Finally, an overview of the stratigraphic ranges and geographic distribution of dispersed megaspores of the genus Sublagenicula is provided in Table 4.

Comparison. - Thomasostrobus longus is thus far the only species of this newly erected genus. Comparison is therefore possible only with morphologically similar species of other lycopsid genera or cones which yielded Sublagenicula-type megaspores (in situ Cadiospora microspores are described for the first time in this paper).

Thomasostrobus longus surprisingly shows the greatest similarity to at least two sigillarian cone species producing Sublagenicula megaspores known in the literature. These are Sigillariostrobus spectabilis Renault and Sigillariostrobus major from Blanzy. Both Renault (1888) and Zeiller (1906) suggested that these cones were most probably born on Sigillaria brardii Brongniart. However, their conclusion is based only on the association of cones with bark or leaves of Sigillaria brardii. Renault's (1888) species Sigillariostrobus spectabilis, which he figured on Plate III, fig. 1 and Plate IV, fig. 1, is a cone reaching more than $5 \mathrm{~cm}$ in diameter, i.e., nearly twice as wide as Thomasostrobus longus. This difference is, however, related to the fact that the distal laminae stand away from the cone body. Thus, Renault's specimen may have been preserved in a more progressed stage of maturation, as the cone body (axis and pedicels) itself is of comparable size and morphology to Thomasostrobus longus. Another of Renault's (1888; Plate IV, fig. 2) specimens represents a small cone fragment that he also connected with Sigillaria brardii. Near the apex of this specimen, triangular pedicels attached to the axis are oriented downward similarly to $T$. longus cones. Renault's (1888) specimen from his Plate III, fig. 1 was later refigured by Zeiller (1906), who provided photographs that included some details of the megaspores. They resemble 

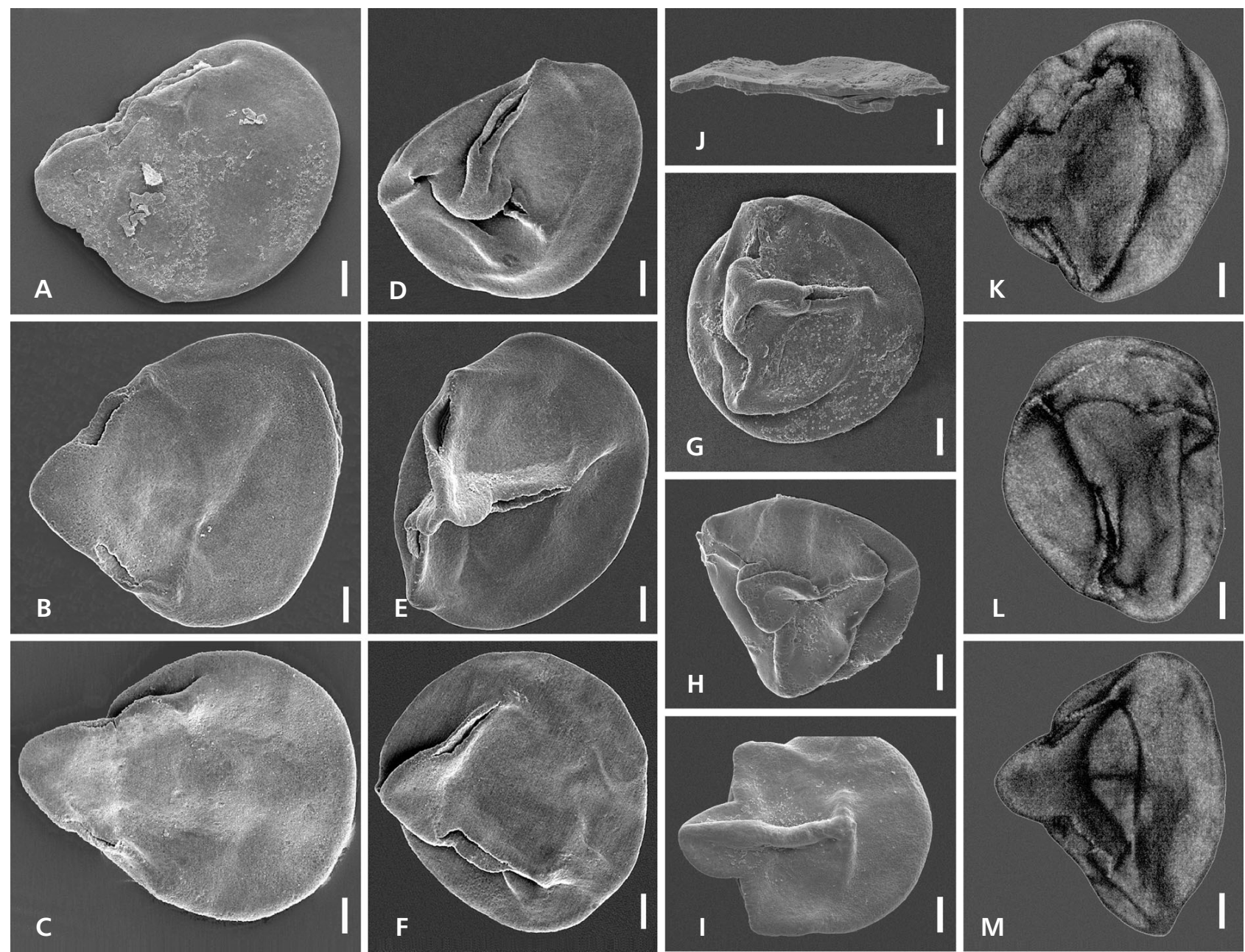

Figure 5. In situ megaspores isolated from the holotype and from the specimen No. E 6354 (Fig. 5J-M) of Thomasostrobus longus sp. nov. from the Radvanice locality, the Intra-Sudetic Basin, and compared with the dispersed species Sublagenicula levis (Zerndt) Dybová-Jachowicz et al. Scale bar $10 \mu \mathrm{m}$. $\bullet$ A-C - lateral view. SEM. $\times 60$. $\bullet$ D-F, H-I - proximal view. SEM. $\times 60 \bullet$ G-I - less mature specimens. G - lateral view, H, I - proximal view. Note distinct horn-like extension of the tecta developed where the tecta meet the arcuate ridges. SEM. $\times 60$. $\bullet$ J - side view. SEM. $\times 100$. $\bullet$, M - lateral view. Reflected light. $\times 60 . \bullet \mathrm{L}-$ proximal view. Reflected light. $\times 60$.

those of the Sublagenicula-type, but nevertheless, the photograph is too poor for a more reliable comparison. Nothing, however, is known about the microspores of either specimen, and therefore, the relationship of Renault's species to $T$. longus remains open.

Sigillariostrobus major is another Sublagenicula-producing species very similar to T. longus. Unfortunately, Germar's (1851) original specimen, described as Volkmania major Germar, is a rather poorly preserved cone fragment from the Wettin Basin, Germany, where the coal rank is too high to be suitable for maceration of spores. Consequently, it is impossible to obtain reliable evidence regarding the systematic position of this cone. Later, Zeiller (1906) described a nearly complete strobilus from Blanzy, SE France which he compared with Germar's Volkmania major. It is a $210 \mathrm{~mm}$ long and $30 \mathrm{~mm}$ wide cylindrical strobilus that, according to Zeiller, was probably born on Sigillaria brardii, and therefore, he re-assigned Germar's species to the genus Sigillariostrobus. Based on Zeiller's (1906) figures, Sigillariostrobus major produced smooth gulate megaspores with diameters varying between 1000 and $1500 \mu \mathrm{m}$ when mature and between 800 and $1000 \mu \mathrm{m}$ when immature. These megaspores are clearly of Sublagenicula-type, however, Zeiller's description and figures are not sufficient for reliable comparison with spores obtained from Thomasostrobus longus. This is also the case for the species Sigillariostrobus spectabilis described by Renault (1888), which Zeiller (1906) later refigured including megaspores. To make the relationship between these French species and T. longus clearer, we tried to find and re-examine Renault's and Zeiller's specimens in the palaeobotanical collection of the Muséum National d'Histoire Naturelle in Paris. Unfortunately, only Sigillariostrobus spectabilis was found in the collection. 

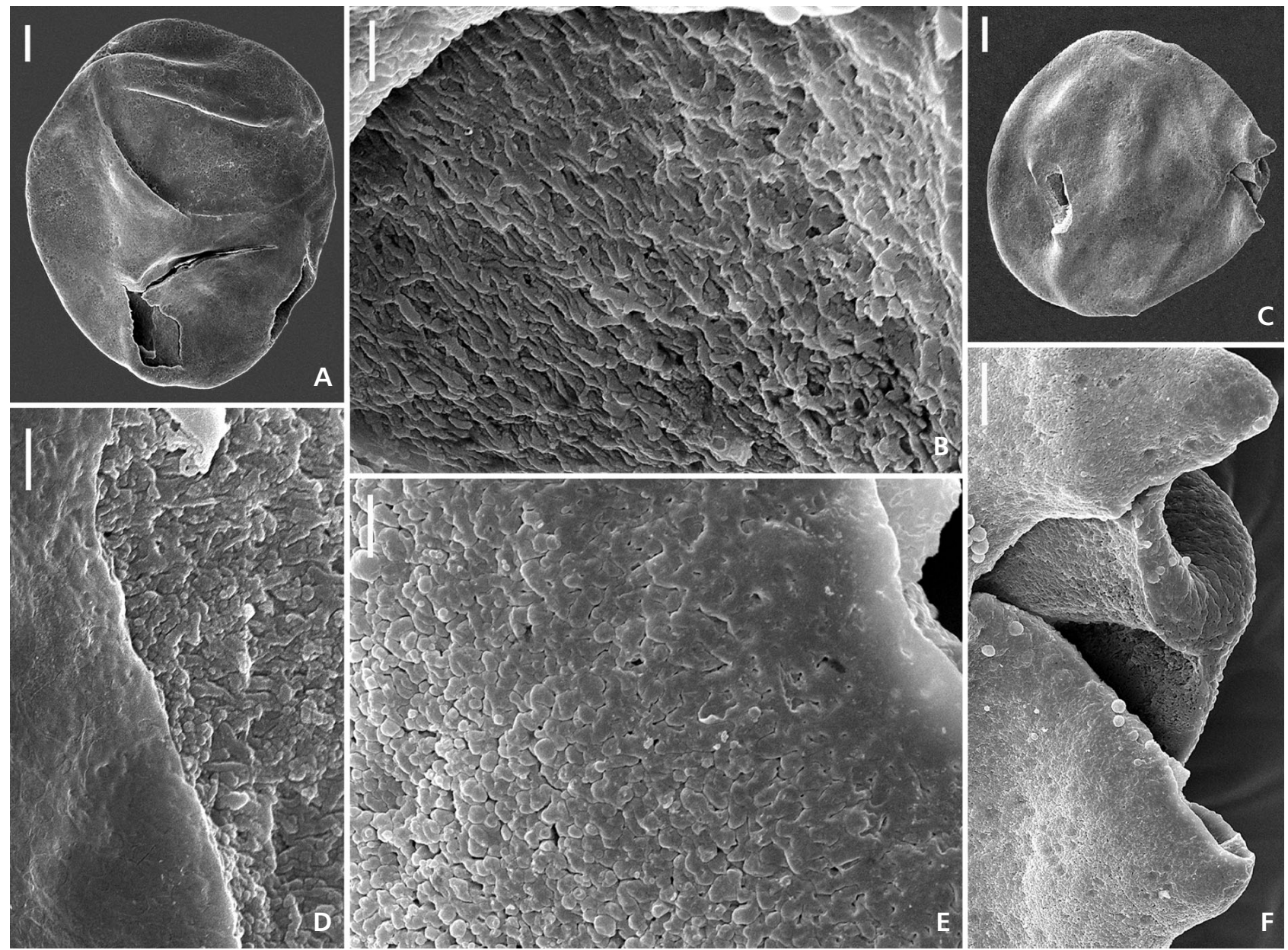

Figure 6. Megaspores isolated from the holotype of Thomasostrobus longus sp. nov. and compared with the dispersed species Sublagenicula levis (Zerndt) Dybová-Jachowicz et al. (magnification $\times 60$, scale bar $100 \mu \mathrm{m} ; \times 500$, scale bar $20 \mu \mathrm{m} ; \times 2000$, scale bar $5 \mu \mathrm{m}$ ). $\bullet$ A - lateral view. SEM. $\times 60$. $\cdot \mathrm{B}$ - detail of Fig. A showing open triradiate ridges and subgula (germinate ruptures). SEM. $\times 500 . \bullet \mathrm{C}-$ detail of Fig. $6 \mathrm{~A}$ and $6 \mathrm{~B}$ showing clearly fibrous structure of inner side of outer subgula layer. Note the orientation of fibres. SEM. $\times 2000$. $\bullet$ D - detail of Fig. 6A in proximity to germinate rupture of subgula where the exine is thinner and nearly compact. Further away from the subgula the external exine surface is granulate to poorly fibrous. SEM. $\times 2000$. $\bullet$ E - lateral view. SEM. $\times 60$. F - detail of Fig. 6A showing exine structure. View of the internal surface of exine. SEM. $\times 2000$.

Samples taken from both ends of this cone fragment where base and apex are missing provided only poorly preserved Sublagenicula megaspores and no microspores. Consequently, although the French specimens are very similar to T. longus from the Intra-Sudetic Basin, we cannot be absolutely sure whether they really represent the same species or not. The same can also be stated regarding the Sublagenicula-producing cones described by Dijkstra (1958) who studied and figured lycopsid cones and their megaspores from the Late Pennsylvanian of Kansas, USA. These cones identified as Sigillariostrobus cf. major are morphologically very similar to $T$. longus. Therefore we re-examined Dijkstra's specimens now stored in the collections of the National Museum of Natural History (Naturalis) in Leiden, Netherlands. Comparison of the Czech and American specimens has not revealed any significant differences in morphology and size, despite the slightly dif- ferent mode of preservation. The American specimens consist of eight small slabs with fragments of cylindrical strobili, including an apical part which is about $20 \mathrm{~mm}$ long and pointed. The base is not preserved on any cone. The cone axis is about $4 \mathrm{~mm}$ wide. Sporophylls are arranged in low angle spirals, being $2.7 \mathrm{~mm}$ apart in the vertical direction. Pedicels are, similarly to the Czech specimens, perpendicular to the cone axis or bent gently downward and between 6 and $7 \mathrm{~mm}$ long. Sporangia are oval, 5.5-6 mm long and $2 \mathrm{~mm}$ high. Distal laminae are triangular with slightly concave margins, entire, and between 19 and $22 \mathrm{~mm}$ long and 2.8 to $3 \mathrm{~mm}$ wide at the base. They are bent towards the cone apex and usually adpressed to the cone body. Megaspores obtained from the specimens 12271, 12275 and 12276 [collection of the National Museum of Natural History (Naturalis) in Leiden, Netherlands] are very similar in size and morphology to those from the 

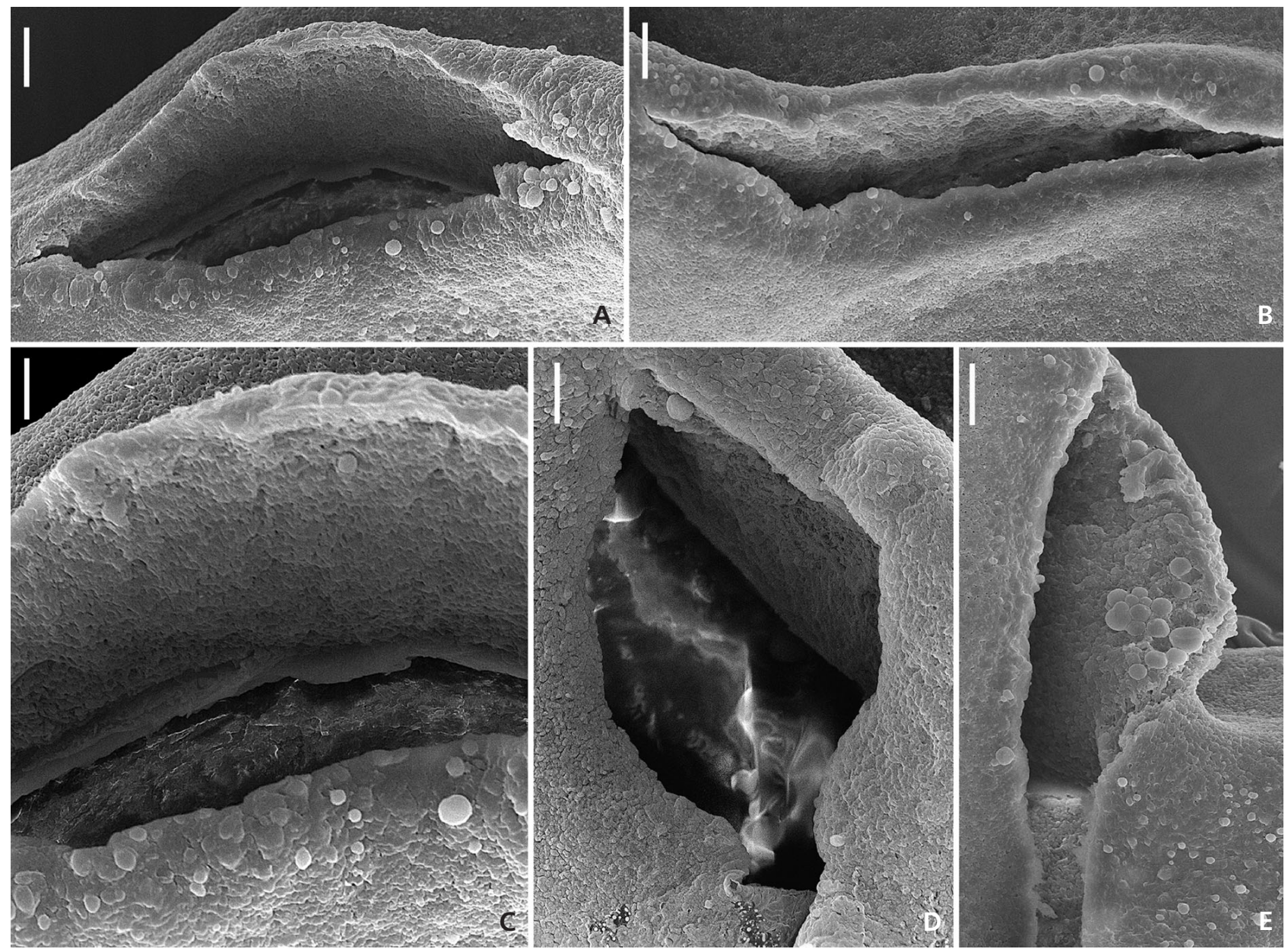

Figure 7. In situ megaspores isolated from the holotype of Thomasostrobus longus sp. nov. and compared with the dispersed species Sublagenicula levis (Zerndt) Dybová-Jachowicz et al. (magnification $\times 500$, scale bar $20 \mu \mathrm{m} ; \times 1000$, scale bar $10 \mu \mathrm{m}$ ). $\bullet$ A-E - details of open triradiate ridges (germinate ruptures). Notice structure of exine and spherical tapetal bodies on the surface of the exine. A - detail of Fig. 5D. SEM. $\times 500$. B - detail of Fig. 5E. SEM. $\times 500$. C - detail of Fig. 5F. Note the smooth and glossy internal surface of exine. SEM. $\times 1000$. D, E - detail of Fig. 5 E. Note the exine consists of three layers. SEM. D $\times 500, \mathrm{E} \times 1000$.

Czech specimens of T. longus. Slight differences can be explained by various stages of maturity and/or abortivity. Therefore we consider megaspores released from Czech and American specimens to be identical, i.e., of the Sublagenicula levis-type. Nearly all of them represent fragments of megasporangiate parts of cones, except specimen No. $12272 \mathrm{a}$, which represents the apical part of a strobilus. This part was presumably microsporangiate, however, no spores have been obtained because of the absence of coal matter. Nevertheless, maceration of the rock in which this specimen is preserved provided a spectrum of dispersed spores, among which Cadiospora was the most abundant element. Although it is quite likely that the American specimens are also bisporangiate, direct evidence of this statement is still absent and we cannot be quite sure. This conclusion is well supported by the recently described new megasporangiate lycopsid cone genus Nudasporestrobus Feng et al., 2008 with the only species N. ningxicus Feng et al. of sigillarian affinity from the Early Pennsylvanian of China. Cones of this genus are monosporangiate with megaspores comparable with the dispersed spore species Sublagenicula nuda (Zerndt \& Nowak) Dybová-Jachowicz et al. It means that Nudasporestrobus and the here erected genus Thomasostrobus, bear megaspores of the same genus (but different species). Moreover, their cones also display a quite high level of similarity. Both genera represent long, narrow cylindrical strobili with sporophylls arranged as a low ascending helix. Cones are of similar size, more than $200 \mathrm{~mm}$ long and about $20 \mathrm{~mm}$ wide. Slight differences seem to be in the shape of the pedicel and laminae which are generaly a little longer in Thomasostrobus. Unfortunatelly, peduncle character of the Nudasporestrobus cone could not be neither confirmed nor excluded in Thomasostrobus cones because all the currently known and here-described specimens lack a cone base. Thus the main difference between Nudasporestrobus 
and Thomasostrobus remains their mono- a bisporangiate character, respectively. The possibility that microspores could not be obtained from the Chinese specimen is quite low since the type collection includes 109 specimens and many of them have preserved apical parts which in Thomasostrobus bears microspores.

Concerning the comparison of Thomasostrobus longus with bisporangiate lycopsid cones, the only other such organ genus bearing micro- and megaspores within a single cone are Moscvostrobus and Flemingites. Comparison with Moscvostrobus is already provided in the section related to a comparison of Thomasostrobus with similar genera. Similarity between $T$. longus with representatives of the genus Flemingites is in both cone morphology and in situ spores. Some representatives of the genus Flemingites have long cylindrical strobili [e.g. F. gracilis (Carruthers) Brack-Hanes \& Thomas] resembling cones of T. longus so comparison might be difficult. The most reliable feature separating such species is their spores. Moreover, most of these Flemingites species are restricted to the Namurian and Westphalian, whereas only exceptionally they occur in the middle Stephanian (Brack-Hanes \& Thomas 1983).

There are also a few cones of the morphogenus Lepidostrobus which can be compared with the genus Thomasostrobus with regard to cone morphology. The most apparent similarity exists between T. longus and Lepidostrobus thomasii Bek \& Opluštil, which is a male cone bearing Lycospora uzunmehmedii Artüz microspores. Lepidostrobus thomasii is a microsporangiate cylindrical strobilus about $20 \mathrm{~mm}$ wide and more than $300 \mathrm{~mm}$ long with an arrangement of sporophylls similar to Thomasostrobus longus. In addition to differences in the sex nature and type of spores produced, which serve as the best tools for their identification, these two cone taxa also differ in their stratigraphic ranges. Lepidostrobus thomasii occurs in lower to middle Westphalian strata, whereas Thomasostrobus longus is known only from the Stephanian.

Stratigraphic range and geographic distribution. - Thomasostrobus longus has been reliably identified only in the Intra-Sudetic Basin, Czech Republic where it occurs in the Radvanice coal group of the Jivka Member (upper part of the Odolov Formation) of the Stephanian B age (Tásler et al. 1979). However, the stratigraphic range and geographic distribution of spores produced by these cones is much larger. Cadiospora-type microspores have a stratigraphic range from Asturian to Autunian. Even larger is the range of Sublagenicula-type megaspores which span the interval from the Viséan to the late Stephanian. The disproportion between the ranges of megaspores and cones indicate that $T$. longus probably was not the only producer of Sublagenicula-type megaspores as indicated by the genus Nudasporestrobus from the middle - late $\mathrm{Na}$ murian of China.
Parent plant. - All the specimens of T. longus from the type collection are only isolated cones, not associated with any type of vegetative lycopsid stem. Consequently, any direct correlation with a parent plant is currently impossible. Šetlík (in Tásler et al. 1979) in the list of flora from the Radvanice group of coals mentioned the following lycopsid species: Lepidodendron gaudrii Renault, Sigillaria brardii, S. ichthyolepis (Presl in Sternberg) and Asolanus camptotaenia Wood. Each of these species could be a potential parent plant. Sigillaria brardii was mentioned as often occuring in association with Sublagenicula-bearing Late Pennsylvanian cones from Blanzy, France (Zeiller 1906) and from Kansas, USA (Dijkstra 1958). The affinity of the Kansas specimens to sigillarians is based on the original discovery of these specimens by Jongman who found them as a single slab containing several cones attached to a stem which he identified as Sigillaria brardii (see details in Dijkstra 1958). Unfortunately, only fragments of cones from this original slab are available in the collection of the National Museum of Natural History (Naturalis) in Leiden, Netherlands. No remains of the parent plant are present in association with the cones except long, grass-like leaves that may belong to Sigillaria brardii. It is, therefore, impossible to confirm Jongman's determination for the stem and whether the cones were really in organic connection to it. Although all these cones apparently resemble those of the here-erected Thomasostrobus longus from the Intra-Sudetic Basin, it is currently impossible to prove whether T. longus is really identical with these cones or not. The main reason is that until now no microspores have been obtained from the French and American specimens. Moreover, any connection between Sigillariostrobus major and Sigillaria brardii as the parent plant also remains unproved.

Ecology. - All known specimens of T. longus are preserved in shale associated with an abundance of fragments of aerial parts of plants. The most common plant remains are flattened casts and impressions of Calamites Schlotheim trunks. The character of the rocks, mode of preservation of plant fossils, and absence of roots indicate that the shale was a lacustrine sediment and that the plant assemblage is of allochtonous origin and probably drifted in from the lake margins or shallows. Therefore, the parent plant of T. longus most likely preferred growing on the clastic substrates of lake coasts or floodplain areas.

\section{An overview of spores related to Thomasostrobus}

\section{Cadiospora miospores}

The genus Cadiospora was established by Kosanke (1950, pp. 166, 167) for: "Radial sub-spherical to roundly triangu- 
lar miospores. Trilete rays are distinct reaching up to three-quarters radius in length, ray ends apparently bifurcating, area contagionis differentiated by its thinner exine, labra well developed. Exine surface laevigate, punctate to infrapunctate, exine normally 5-10 $\mu \mathrm{m}$ thick, usually thicker beyond the ray-ends and developing one or more mounds." Kosanke did not mention the occurrence of a cingulum or equatorial thickening (crassitudo).

Bharadwaj (1954) proposed the morphologically similar genus Gravisporites Bharadwaj, which he distinguished from Cadiospora by its massive equatorial crassitudo but he considered that Cadiospora has a cingulum. Bharadwaj (1954) established Gravisporites sphaerus (Butterworth \& Williams) Bharadwaj (formerly Cadiospora sphaera Butterworth \& Williams) as the type species of Gravisporites.

Venkatachala \& Bharadwaj (1964) described six dispersed species of Cadiospora, including four new ones: C. aggera Bharadwaj \& Venkatachala, C. laminata Bharadwaj \& Venkatachala, C. tumula Bharadwaj \& Venkatachala, and C. absoluta Bharadwaj \& Venkatachala. Peppers (1964) erected another species, C. fifthiana, characterised by its relatively small diameter and a thin labrum. Clendening (1975) reported miospores described as "Genus A" that resemble Cadiospora.

Boháčová (1962) proposed the new species Cadiospora bohemica Boháčová from the Stephanian B of the Kladno-Rakovník Basin as the first Cadiospora species from the Czech coalfields.

Kalibová (1963) proposed the dispersed species Lycospora butterworthii Kalibová, which she later (Kalibová-Kaiserová 1972) assigned to Cadiospora as C. butterworthii (Kalibová) Kalibová-Kaiserová. However, this species possesses a strange equatorial thickening, interpreted as the cingulum, and its classification as Cadiospora is thus questionable. In 1972, Kalibová-Kaiserová also determined five Cadiospora species from the Stephanian B of the Mšeno Basin, Czech Republic: $C$. butterworthii, three new forms of Cadiospora (C. magna f. major Kalibová-Kaiserová, C. magna f. minor Kalibová-Kaiserová, and C. magna f. plicata Kalibová-Kaiserová), and one species of Gravisporites (G. sphaerus Kosanke \& Bharadwaj). The list of dispersed miospores of Cadiospora and Gravisporites is summarised in Table 1.

Miospores of the Cadiospora-type occur mainly in the Stephanian of the Czech Republic (Drábková in Pešek 1994), but their records are also known from Asturian strata of the Pilsen, Kladno-Rakovník, Mšeno and Mnichovo Hradiště basins, and from Asturian to Autunian strata of the Intra-Sudetic and Krkonoše Piedmont basins. The geographic and stratigraphic occurrences of miospores of Cadiospora and Gravisporites in the Pennsylvanian of the Czech Republic are given in Tables 2 and 3.

The systematic position of Cadiospora had been changed. Potonié \& Kremp (1954) referred spores of this
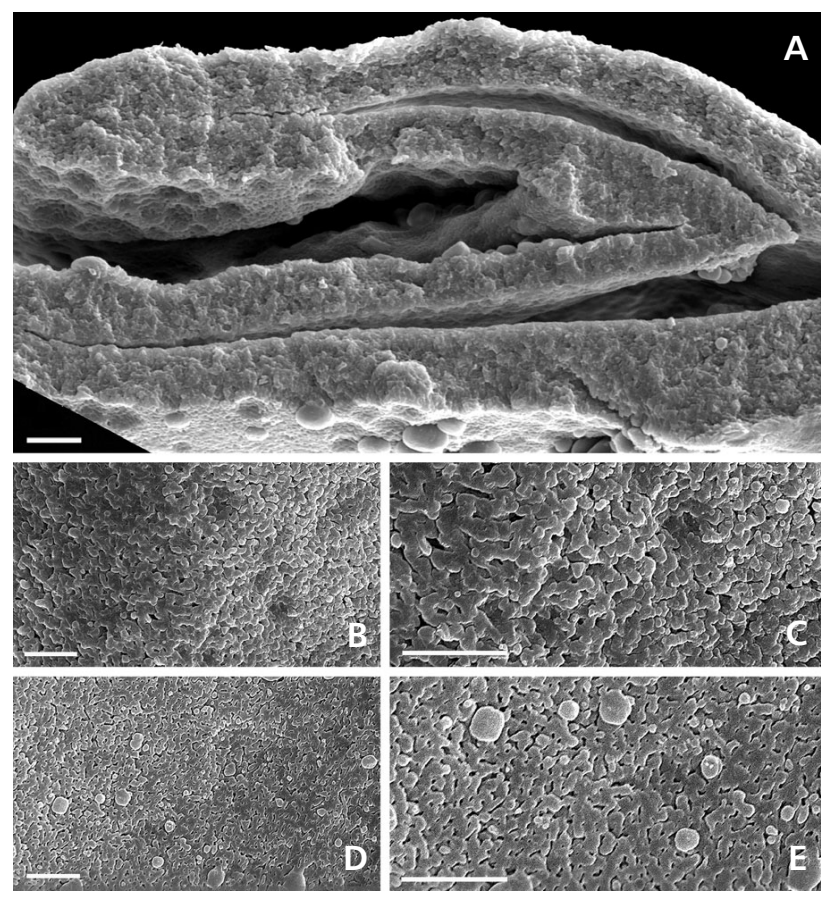

Figure 8. In situ megaspores isolated from the holotype of Thomasostrobus longus sp. nov. and compare with the dispersed species $S u b$ lagenicula levis (Zerndt) Dybová-Jachowicz et al. (magnification $\times 500$ and $\times 1000$, scale bar $10 \mu \mathrm{m})$. $\bullet$ A - detail of Fig. 5J. Transverse cut through subgula and megaspore body. SEM. $\times 500$. $・$ B, C - detail of Fig. 5D showing external surface of the subgula SEM. $\mathrm{B} \times 500, \mathrm{C} \times 1000$. - D, E - detail of Fig. 5B showing external distal surface of the megaspore. SEM. D $\times 500, \mathrm{E} \times 1000$.

type to trilete cingulate spores of the turma Zonotriletes, infraturma Cingulati, and supposed that Cadiospora possesses an equatorial thickening (cingulum). Venkatachala \& Bharadwaj (1964) redefined Cadiospora as trilete spores without a cingulum (turma Azonotriletes, infraturma Laevigati) (i.e., they confirmed Kosanke's (1950) original concept). Cadiospora sensu Smith \& Butterworth (1967) belongs to subturma Azonotriletes, infraturma Apiculati and subinfraturma Granulati (i.e., among non-cingulate taxa). Most Czech Carboniferous palynologists (e.g., Boháčová 1962, Kalibová-Kaiserová 1978, Valterová 1979) followed the concept of Potonié and Kremp and considered Cadiospora to be among the cingulate taxa.

\section{Cadiospora vs. Gravisporites}

It seems that there may be three spore types formerly assigned to the dispersed genera Cadiospora and Gravisporites. Spores of the Cadiospora-type sensu Kosanke (1950) possess a labrum, arcuate ridges, laesurae with bifurcating ends, rays of the trilete mark reaching at least three-quarters of the radius, and the exine being up to $3 \mu \mathrm{m}$ thick.

The second type was described by Bharadwaj (1954), 
Table 1. Dispersed Carboniferous miospores of the Cadiospora and Gravisporites-type and their characteristics.

\begin{tabular}{|c|c|c|}
\hline Dispersed Cadiospora & $\begin{array}{l}\text { Diameter } \\
(\mu \mathrm{m})\end{array}$ & Remarks \\
\hline Cadiospora laminata Venkatachala \& Bharadwaj & $90-110$ & Exine $8-10 \mu \mathrm{m}$ thick, labrum $4 \mu \mathrm{m}$, infrapunctate sculpture, Y $1 / 2-2 / 3 \mathrm{r}$ \\
\hline Cadiospora tumula Venkatachala \& Bharadwaj & $110-130$ & Labrum $6 \mu \mathrm{m}$, exine $10 \mu \mathrm{m}, \mathrm{Y} 1 / 2 \mathrm{r}$ \\
\hline Cadiospora aggera Venkatachala \& Bharadwaj & $90-120$ & Labrum $4 \mu \mathrm{m}$, exine $10 \mu \mathrm{m}, \mathrm{Y} 2 / 3 \mathrm{r}$, infrapunctate with irregular "mounds" \\
\hline Cadiospora absoluta Venkatachala \& Bharadwaj & $110-130$ & Y $2 / 3 r$, exine $10 \mu \mathrm{m}$ thick, infrapunctate with "mounds" \\
\hline Cadiospora fithiana Peppers & $56-75$ & Labrum 3-6.5 $\mu \mathrm{m}$, exine 3-4 $\mu \mathrm{m}$, punctate and granulate sculpture \\
\hline Cadiospora magna Kosanke & $95-125$ & Labrum 4-5 $\mu \mathrm{m}$, punctate to granulose sculpture, exine $6-8 \mu \mathrm{m}$ \\
\hline Genus A sensu Clendening & $76-100$ & Exine $1-1.5 \mu \mathrm{m}$ thick, laevigate, finely granulate, rugose \\
\hline Genus B sensu Clendening & $58-96$ & Exine $4-10 \mu \mathrm{m}$ thick, laevigate, microgranulate \\
\hline Cadiospora bohemica Boháčová & 79-94 & Exine 3-3.5 $\mu \mathrm{m}$ thick, bifurcate rays of trilete mark, exine punctate, microgranulate \\
\hline Cadiospora magna f. maior Kalibová-Kaiserová & $88-140$ & Labrum 4-6 $\mu \mathrm{m}$, bifurcate, exine finely granulate and verrucate, verrucae $3-6 \mu \mathrm{m}$ \\
\hline Cadiospora magna f. minor Kalibová-Kaiserová & $60-88$ & Labrum $4-8 \mu \mathrm{m}$, exine $6-10 \mu \mathrm{m}$ thick, exine granulate \\
\hline Cadiospora magna f. plicata Kalibová-Kaiserová & $80-110$ & Labrum 2-4 $\mu \mathrm{m}$, curvaturae, exine laevigate \\
\hline Cadiospora butterworthi (Kalibová) Kalibová-Kaiserová & $60-100$ & Cingulum $4-10 \mu \mathrm{m}$, labrum $2-4 \mu \mathrm{m}$ thick \\
\hline
\end{tabular}

who proposed the new genus Gravisporites for spores with shorter rays of the trilete mark (one-half to three-quarters of the radius), a more thickened exine $(8-10 \mu \mathrm{m})$, stronger arcuate ridges and an absence of bifurcated laesurae. Some authors (e.g. Smith \& Butterworth 1967) considered both genera as synonymous, i.e. Gravisporites as a junior synonymum of Cadiospora based on the opinion that both genera lack cingulum and therefore type species of both genera Gravisporites sphaera and Cadispora magna are synonymous.

Miospores of Cadiospora sensu Venkatachala \& Bharadwaj (1964) are of a similar type in that they have a thickened exine $(8-10 \mu \mathrm{m})$. In comparison with Cadiospora sensu Kosanke, however, rays from the trilete mark are not as long and the labrum is not as prominent (if present). These miospores more closely resemble some spores of the Punctatisporites-type rather than Cadiospora or Gravisporites. They are especially similar to some specimens of the Punctatisporites obesus-type, which are characterised by a thickened exine and comparable bifurcating laesurae. Spores of the Punctatisporites obesus-type were produced by some species of Sphenophyllum Koenig (e.g., Bek \& Opluštil 1998), whereas spores of the Cadiospora-type (sensu Kosanke) were produced by arborescent sigillarian lycopsids. Other species of Punctatisporites (e.g., P. limbatus Hacquebard, P. bifurcatus Kalibová-Kaiserová) or even the Permian spore genus Callumispora Bharadwaj \& Shrivastava may also resemble thick-walled spores of the Punctatisporites obesus-type (i.e., Cadiospora sensu Venkatachala \& Bharadwaj (1964)). The determination of some miospores assigned by Venkatachala \& Bharadwaj (1964) to Cadiospora is questionable, and these spores may instead resemble some spores of the Punctatisporites-type, mainly due to the indistinct labrum or arcuate ridges along the suturae.
Cadiospora and Gravisporites have different morphologies based on the original diagnoses given by Kosanke (1950) and Bharadwaj (1954), respectively. Cadiospora was defined as a non-cingulate genus and Gravisporites as a cingulate one. Later, Bharadwaj (1957), Venkatachala \& Bharadwaj (1964) and Smith \& Butterworth (1967) suggested that Cadiospora and Gravisporites lack a cingulum and possess only a thickened exine (from 5-10 $\mu \mathrm{m}$ ), earlier considered as an equatorial thickening. However, some miospores assigned to Cadiospora do not possess such a thick exine. For example, Gravisporites sphaerus illustrated by Peppers (1964) possesses a prominent labrum and contact area, but the exine is relatively thin (up to 2-3 $\mu \mathrm{m}$ ). Another species of this type, Cadiospora fithiana Peppers described by Peppers (1964), also has a thinner exine (3-4 $\mu \mathrm{m})$, and it is evident that the exine of both spore species does not reach the thickness $(5-10 \mu \mathrm{m})$ mentioned by Bharadwaj (1955) and Venkatachala \& Bharadwaj (1964). These spores may instead correspond to Cadiospora sensu Venkatachala \& Bharadwaj (1964). The variable size of the labrum was documented by Clendening (1974) who illustrated specimens of $C$. magna with a relatively thin (Pl. 2, fig. 1) and broad (Pl. 1, fig. 18; Pl. 2, figs 2, 3, 5, 6) labrum.

All spores of the Cadiospora-type described by Kosanke (1950), Peppers (1964), Boháčová (1962), Kalibová-Kaiserová (1978) and Valterová (1973-5) represent the same type of spores, and correspond to Cadiospora sensu Kosanke.

The third type is represented by Gravisporites miospores, which differ from Cadiospora sensu Kosanke by having a more thickened labrum and by lacking the bifurcation of laesurae.

Smith \& Butterworth (1967) considered that there was no reason for separating Cadiospora sphaera (formerly Gravisporites sphaerus) from Cadiospora magna. Miospores formerly assigned to Cadiospora and Gravisporites are of 
Table 2. Stratigraphic and geographic occurrences of miospores of the Cadiospora and Gravisporites-types and dispersed Sublagenicula levis megaspores in the Plzeň, Kladno-Rakovník and Mšeno-Roudnice basins, Czech Republic (from Pešek et al. 2001).

\begin{tabular}{|c|c|c|c|c|c|c|c|}
\hline \multirow{3}{*}{$\begin{array}{l}\text { Dispersed Cadiospora } \\
\text { and Gravisporites miospores and } \\
\text { Sublagenicula megaspores }\end{array}$} & \multicolumn{3}{|c|}{ Pilsen Basin } & Kladno-Rakovník & \multicolumn{3}{|c|}{ Mšeno-Roudnice Basin } \\
\hline & \multirow{2}{*}{$\begin{array}{c}\text { Asturian } \\
\text {-Cantabrian } \\
\text { Nýřany } \\
\text { Member }\end{array}$} & \multirow{2}{*}{$\begin{array}{l}\text { Barruelian } \\
\text { Týnec Fm. }\end{array}$} & \multirow{2}{*}{$\begin{array}{c}\text { Stephanian B } \\
\text { Otruby } \\
\text { Member }\end{array}$} & \multirow{2}{*}{$\begin{array}{c}\text { Stephanian B } \\
\text { Otruby Member }\end{array}$} & \multirow{2}{*}{$\begin{array}{c}\text { Asturian } \\
\text {-Cantabrian } \\
\text { Nýřany } \\
\text { Member }\end{array}$} & Stephanian B & \multirow{2}{*}{$\begin{array}{l}\text { Stephanian C } \\
\text { Líně Fm. }\end{array}$} \\
\hline & & & & & & $\begin{array}{l}\text { Jelenice Otruby } \\
\text { Member Member }\end{array}$ & \\
\hline \multicolumn{8}{|l|}{ Cadiospora bohemica } \\
\hline \multicolumn{8}{|l|}{ Cadiospora magna f. maior } \\
\hline \multicolumn{8}{|l|}{ Cadiospora magna f. minor } \\
\hline \multicolumn{8}{|l|}{ Cadiospora magna f. plicata } \\
\hline \multicolumn{8}{|l|}{ Cadiospora magna } \\
\hline \multicolumn{8}{|l|}{ Gravisporites sphaerus } \\
\hline Sublagenicula levis & & & & & & & \\
\hline
\end{tabular}

Table 3 Stratigraphic and geographic occurrences of miospores of the Cadiospora and Gravisporites-types and dispersed Sublagenicula levis megaspores in the Intra-Sudetic, Krkonoše Piedmont and Mnichovo Hradiště basins, Czech Republic (from Pešek et al. 2001).

\begin{tabular}{|c|c|c|c|c|c|c|c|}
\hline \multirow{3}{*}{$\begin{array}{l}\text { Dispersed Cadiospora and } \\
\text { Gravisporites miospores and } \\
\text { Sublagenicula levis megaspores }\end{array}$} & \multicolumn{2}{|c|}{ Intra-Sudetic Basin } & \multicolumn{3}{|c|}{ Krkonoše Piedmont Basin } & \multirow{2}{*}{\multicolumn{2}{|c|}{$\begin{array}{c}\text { Mnichovo Hradiště Basin } \\
\text { Stephanian B }\end{array}$}} \\
\hline & $\begin{array}{c}\text { Barruelian- } \\
\text { Stephanian B }\end{array}$ & Stephanian C & Stephanian B & Stephanian C & Autunian & & \\
\hline & Jívka Member & $\begin{array}{c}\text { Vernéřovice } \\
\text { Member }\end{array}$ & $\begin{array}{c}\text { Syřenov } \\
\text { Formation }\end{array}$ & $\begin{array}{c}\text { Semily } \\
\text { Formation }\end{array}$ & Vrchlabí Fm. & $\begin{array}{c}\text { Lower Syřenov } \\
\text { Formation }\end{array}$ & $\begin{array}{c}\text { Upper Syřenov } \\
\text { Formation }\end{array}$ \\
\hline \multicolumn{8}{|l|}{ Cadiospora bohemica } \\
\hline \multicolumn{8}{|l|}{ Cadiospora magna f. maior } \\
\hline \multicolumn{8}{|l|}{ Cadiospora magna f. minor } \\
\hline \multicolumn{8}{|l|}{ Cadiospora magna f. plicata } \\
\hline \multicolumn{8}{|l|}{ Cadiospora magna } \\
\hline \multicolumn{8}{|l|}{ Gravisporites sphaerus } \\
\hline Sublagenicula levis & & & & & & & \\
\hline
\end{tabular}

the same type and may both belong to the dispersed spore genus Cadiospora. The present authors believe that this assumption can only be reliably confirmed by the discovery of spores of both types in situ, which will verify whether they were produced by the same or different parent plants.

Microspores isolated from Thomasostrobus longus are characterised by a relatively thin exine, a prominent labrum, and long rays from the trilete mark. Accordingly, they belong to forms of Cadiospora with a relatively thin exine and cannot be compared to Cadiospora sensu Venkatachala \& Bharadwaj or to Gravisporites.

\section{Sublagenicula megaspores}

In 1936, Nowak \& Zerndt described the laevigate gulate megaspore species Lagenicula nuda (Type 43) from the Namurian A of the Upper Silesian Basin. Later, Zerndt (1937) reported another laevigate gulate species L. levis (Type 45) from the Stephanian of the Czech Republic. Zerndt (1937, p. 588) considered L. nuda and L. levis to be "very similar" and admitted that the only reason for erecting the new species L. levis was the long stratigraphic gap between the occurrences of both taxa.

Potonié \& Kremp (1955) proposed the megaspore genus Lagenoisporites Potonié \& Kremp as characterised by the occurrence of gula and laevigate sculpture on the exine. Piérart (1965) made the new combination Lagenoisporites levis. Dybová-Jachowicz et al. (1979), in their revision of Carboniferous gulate megaspores, proposed four types of gula (hologula, subgula, anguligula and crassigula), redefined the genera Lagenicula (Bennie \& Kidston) Potonié \& Kremp, Lagenoisporites and Setosisporites (Ibrahim) Potonié \& Kremp, and proposed the new genera Sublagenicula Dybová-Jachowicz et al., Auritolagenicula Dybová-Jachowicz et al., and Crassilagenicula Dybová-Jachowicz et al.

Sublagenicula includes twelve species characterised by prominent and large subgula and laevigate to variously ornamented exine. The laevigate taxa consist of Sublagenicula levis (Zerndt) Dybová-Jachowicz et al. and Sublagenicula nuda (Nowak \& Zerndt) Dybová-Jachowicz et al. However, Jachowicz (1966) and Kalibová-Kaiserová 
Table 4. Comparison of in situ megaspores of Thomasostrobus longus sp. nov., Sigillariostrobus cf. major (German) Zeiller, and some selected dispersed megaspores Sublagenicula-type.

\begin{tabular}{|c|c|c|c|c|c|c|c|}
\hline $\begin{array}{l}\text { In situ and dispersed } \\
\text { megaspores and their } \\
\text { references }\end{array}$ & $\begin{array}{l}\text { Length }(\mathrm{L}) \text { of the } \\
\text { spore along polar } \\
\text { axis } \\
\text { Width }(\mathrm{W}) \text { of the } \\
\text { spore }(\mu \mathrm{m})\end{array}$ & $\begin{array}{l}\text { Height }(\mathrm{H}) \text { of the } \\
\text { gula } \\
\text { Width }(\mathrm{W}) \text { of the } \\
\text { gula }(\mu \mathrm{m})\end{array}$ & $\begin{array}{l}\text { Length (L) } \\
\text { Height }(\mathrm{H}) \\
\text { Width }(\mathrm{W}) \\
\text { of the tecta }\end{array}$ & $\begin{array}{l}\text { Length of } \\
\text { the laesurae } \\
(\mu \mathrm{m})\end{array}$ & $\begin{array}{l}\text { Height }(\mathrm{H}) \\
\text { Width }(\mathrm{W}) \\
\text { of the arcuate } \\
\text { ridges }(\mu \mathrm{m})\end{array}$ & $\begin{array}{l}\text { Thickness } \\
\text { of the spore } \\
\text { wall }\end{array}$ & Remarks \\
\hline $\begin{array}{l}\text { Megaspores isolated } \\
\text { from Thomasostrobus } \\
\text { longus, herein } \\
\text { (Stephanian B) }\end{array}$ & $\begin{array}{l}\mathrm{L}: 633(828) 1012 \\
\mathrm{~W}: 600(710) 886\end{array}$ & $\begin{array}{l}\mathrm{H}: 177(230) \\
\mathrm{W}: 278\end{array}$ & $\begin{array}{l}\mathrm{L}: 404(471) 557 \\
\mathrm{~W}: 30\end{array}$ & $180-250$ & $\mathrm{~W}: 30$ & $15-20$ & $\begin{array}{l}50 \text { specimens } \\
\text { Exina laevigate, faintly } \\
\text { glossy with hepispherical } \\
\text { ubish bodies } \\
(\text { diameter } 2-8 \mu \mathrm{m})\end{array}$ \\
\hline $\begin{array}{l}\text { Dispersed Lagenicula } \\
\text { levis in Zerndt } 1937 \\
\text { (Stephanian B) }\end{array}$ & $\begin{array}{l}\mathrm{L}: 790(909) 1020 \\
W: 610(684) 750\end{array}$ & $\begin{array}{l}\mathrm{H}: 240-290 \\
\mathrm{~W}: 250-310\end{array}$ & $\begin{array}{l}\text { L: } 350-570 \\
\text { H: } 30 \\
\text { W: } 30\end{array}$ & - & $\begin{array}{l}\mathrm{H}: 10-15 \\
\mathrm{~W}: 30-50\end{array}$ & $10-15$ & Exina laevigate \\
\hline $\begin{array}{l}\text { Megaspores isolated } \\
\text { from Sigillariostrobus cf. } \\
\text { major in Dijkstra } 1958 \\
\text { (Stephanian) }\end{array}$ & $\begin{array}{l}\text { L: } 660-1350 \\
\text { W: } 660-1350 \\
\text { Unmatured } \\
\text { L: } 630\end{array}$ & $\begin{array}{l}\mathrm{H}: 240 \\
\mathrm{~W}: 250-310\end{array}$ & $\begin{array}{l}\text { L: } 480 \\
\text { W: } 30\end{array}$ & - & - & 15 & $\begin{array}{l}\text { Exina laevigate, faintly } \\
\text { glossy with hepispherical } \\
\text { ubish bodies (diameter } \\
5-8 \mu \mathrm{m})\end{array}$ \\
\hline $\begin{array}{l}\text { Megaspores isolated } \\
\text { from Sigillariostrobus cf. } \\
\text { major, herein } \\
\text { (Stephanian B) }\end{array}$ & $\begin{array}{l}\text { L: } 650(886) 1076 \\
\text { W: } 538(653) 847 \\
\text { Unmatured } \\
\text { L: } 514-630\end{array}$ & $\begin{array}{l}\text { H: 180-295 } \\
\text { W: }\end{array}$ & $\begin{array}{l}\mathrm{L}: 450(478) 520 \\
\mathrm{~W}: 30\end{array}$ & 200 & $\mathrm{~W}: 25-30$ & $10-20$ & $\begin{array}{l}20 \text { specimens } \\
\text { Hepispherical ubish } \\
\text { bodies (diameter } 3-8 \mu \mathrm{m} \text { ) }\end{array}$ \\
\hline $\begin{array}{l}\text { Dispersed Sublagenicula } \\
\text { levis, Jiřina Mine, herein } \\
\text { (Stephanian B) }\end{array}$ & $\begin{array}{l}\text { L: } 633(828) 1012 \\
\text { W: } 520-840 \\
\text { Unmatured } \\
\text { L: } 480-620\end{array}$ & H: $200-300$ & $\begin{array}{l}\mathrm{L}: 404(471) 560 \\
\mathrm{~W}: 30\end{array}$ & $100-200$ & $\mathrm{~W}: 20-30$ & $10-15$ & $\begin{array}{l}50 \text { specimens } \\
\text { Exina laevigate, faintly } \\
\text { glossy, with } \\
\text { hemispherical ubish } \\
\text { bodies }\end{array}$ \\
\hline $\begin{array}{l}\text { Dispersed Sublagenicula } \\
\text { nuda, herein (Bolsovian) }\end{array}$ & $\begin{array}{l}\text { L: } 590(950) 1200 \\
W: 620(880) 110\end{array}$ & $\begin{array}{l}\mathrm{H}: 100-340 \\
\mathrm{~W}: 150-300\end{array}$ & $\mathrm{~W}: 40-50$ & - & W: 40 & $40-50$ & Laevigate, glossy \\
\hline $\begin{array}{l}\text { Dispersed Triletes } \\
\text { hispanicus in Dijkstra } \\
1955 \text { (Stephanian) }\end{array}$ & $\begin{array}{l}50 \text { specimens } \\
\text { L: } 425(1029) 1520 \\
W: 400(845) 1300\end{array}$ & $\begin{array}{l}\text { H: } 180-325 \\
W: 170-400\end{array}$ & $\begin{array}{l}\text { W: } 20-80 \\
\mathrm{H}: 30-40\end{array}$ & - & $\begin{array}{l}\mathrm{H}: 20-30 \\
\mathrm{~W}: 10-40\end{array}$ & 10 & $\begin{array}{l}\text { Exina laevigate somewhat } \\
\text { lucent, shiny, chestnut. } \\
\text { Abortive spores present }\end{array}$ \\
\hline
\end{tabular}

Table 5. Overview of megaspores that could be produced by cones of the Thomasostrobus-type.

\begin{tabular}{|c|c|c|c|c|}
\hline Megaspores & References & Country & Basin, Formation & Age \\
\hline Lagenicula levis & Zerndt (1937) & Czech Republic & Intra-Sudetic Basin, Kladno-Rakovník Basin & Stephanian B \\
\hline Lagenoisporites nudus & Kalibová (1964) & Czech Republic & Plzeň Basin & Stephanian B \\
\hline Triletes hispanicus & Dijkstra (1955a) & Spain & Puertollano Basin & Stephanian \\
\hline Lagenicula levis & Piérart (1956) & France & De Blanzy and de Decazeville Basin & Stephanian \\
\hline Triletes levis & Winslow (1959) & Illinois, USA & Illinois Basin McLeansboro Group & Upper Pennsylvanian \\
\hline Lagenoisporites hispanicus & Piérart (1961) & China & - & ?Westphalian-Permian \\
\hline Lagenoisporites cf. hispanicus & Piérart (1965) & France & Decazeville Basin & Stephanian \\
\hline Lagenoisporites cf. levis & Piérart (1965) & France & Decazeville Basin & Stephanian \\
\hline Lagenoisporites levis & Kalibová $(1967,1978)$ & Czech Republic & Central Bohemian basins & Stephanian B \\
\hline Sublagenicula levis & Oshurkova (2001) & Kazachstan & Karaganda and Ekibastus basins & Stephanian \\
\hline
\end{tabular}

(1978) reported both species from Westphalian strata for the first time. Therefore, Dybová-Jachowicz et al. (1987) later revised the genus Sublagenicula, and proposed that Lagenicula levis was synonymous with Sublagenicula nuda due to the closely similar morphologies and stratigraphic ranges of both taxa. Triletes hispanicus described by Dijkstra (1955) from the Stephanian of Spain was also considered by Dybová-Jachowicz et al. (1987) to be synonymous with Sublagenicula nuda.
The megaspores mentioned above are all morphologically simple and characterised by a smooth unsculptured exine. Consequently, particular species are very similar to each other and therefore often difficult to distinguish from one another. To overcome this difficulty, the ultrastructure of the megaspore exine must be studied using SEM and TEM techniques. Thus Hemsley \& Galtier (1991), who investigated Sublagenicula nuda megaspores from the Viséan strata of Estnost and Roanne, France, confirmed that the ultrastructure 
of the French megaspores differ from that of Sublagenicula nuda described from the early Stephanian Herrin No. 6 Coal (Illinois Basin, USA) by Taylor (1990). The exine of the American form is thinner, more densely constructed and the outermost granular region is not apparent.

\section{Summary and conclusions}

The new lycopsid organ genus Thomasostrobus is proposed here for bisporangiate strobili bearing Cadiosporatype microspores and Sublagenicula megaspores. It is similar to the Flemingites cones of lepidodendrid lycopsids but differs in its in situ spores. Although the parent plant of the only species, Thomasostrobus longus, is currently unknown, some published specimens of morphologically similar cones which produced Sublagenicula megaspores (from coalfields in the USA and France) indicate that the parent plant might be Sigillaria brardii.

Dispersed miospores of the Cadiospora-type occur from the Asturian (Asturian) to the Permian in the Czech Republic whereas megaspores of Sublagenicula nuda sensu Dybová-Jachowicz et al. (1987) are reported from the Bolsovian to the Stephanian in this country. An even longer stratigraphic range from the Viséan is reported from western European coalfields. The long stratigraphic occurrence of megaspores of the Sublagenicula nuda-type sensu Dybová-Jachowicz et al. (1987) indicates that the strobilus Thomasostrobus longus is unlikely to be their sole producer. Our comparison of dispersed megaspores of this type from the Bolsovian and Stephanian of the Czech Republic indicates that the subtle differences observed most probably represent independent species produced by different parent plants. Results of the study of both dispersed and in situ megaspores show that Sublagenicula nuda sensu Dybová-Jachowicz et al. (1987) is a cumulative species. We believe that Sublagenicula levis represents an independent species, the stratigraphic onset of which is accompanied by the first appearance of Cadiospora microspores.

\section{Acknowledgement}

We are very grateful to Arden Bashforth from Dalhousie University in Halifax, Canada for correcting the English in the text. Arden Bashforth, William DiMichele, Barry Thomas and Josef Pšenička are thanked for their critical remarks which significantly improved the quality of the paper. We also highly acknowledge financial support from the Grant Agency of the Academy of Sciences of the Czech Republic (project A 3013902), financial support from the Research programme (AVOZ30130516) of the Institute of Geology, v.v.i., Academy of Sciences of the Czech Republic, and the project MSM 0021620855 of the Faculty of Science, Charles University. Special thanks to Zbyněk Šimůnek from the Czech Geological Survey, Prague, who found and loaned the holotype. Milan
Libertín and Radek Labuta from the National Museum in Prague are acknowledge for providing two other specimens for study. Johanna van Konijnenburg-van Cittert and Isabel van Waveren from the National Museum of Natural History (Naturalis) in Leiden, Netherlands, are thanked for providing the American specimens for comparison and documentation. The authors thank Jan Malec from the laboratory of the Czech Geological Survey, Prague for taking SEM digital images of spores.

\section{References}

BATEMAN, R.M., DimiChELE, W.A. \& Willard, D.A. 1992. Experimental cladistic analysis of anatomically preserved arborescent lycopsids from the Carboniferous of Euramerica: an essay on paleobotanical phyllogenetics. Annals of the Missouri Botanical Garden 79, 500-559. DOI 10.2307/2399752

BEK, J. \& OPLUŠTIL, S. 1998. Some lycopsid, sphenopsid and pteropsid fructifications and their miospores from the Upper Carboniferous basins of the Bohemian Massif. Palaeontographica B 248, 127-161.

BEK, J. \& OPLUŠTIL, S. 2004. Palaeoecological constraints of some Lepidostrobus cones and their parent plants from the Late Palaeozoic continental basins of the Czech Republic. Review of Palaeobotany and Palynology 131, 49-89.

DOI 10.1016/j.revpalbo.2004.02.008

BEK, J. \& OPLUŠTIL, S. 2006. Six rare Lepidostrobus species from the Pennsylvanian of the Czech Republic and their bearing on the classification of lycospores. Review of Palaeobotany and Palynology 139, 211-226. DO] 10.1016/j.revpalbo.2006.01.003

BHARADWAJ, D.C. 1954. Einige neue Sporengattungen des Saarkarbons. Neues Jahrbuch für Geologie und Paläontologie, 512-525.

BHARADWAJ, D.C. 1955. The spore genera from the Upper Carboniferous coals of the Saar and their value in stratigraphical studies. The Palaeobotanist 4, 119-149.

BHARADWAJ, D.C. 1957. The spore flora of the Velener Schichten (Lower Asturian) in the Ruhr Coal Measures. Palaeontographica B 102, 110-138.

BOHÁČOVÁ, M. 1962. Palynologický výzkum kounovské sloje v kladensko-rakovnické pánvi. Sborník Ústředního ústavu geologického 27, 1-37.

BRACK-HANES, S.D. \& THOMAS, B.A. 1983. A re-examination of Lepidostrobus Brongniart. Botanical Journal of the Linnean Society 86, 125-133. DOI 10.1111/j.1095-8339.1983.tb00720.x

BRONGNIART, A. 1828-1838. Historie des végétaux fossiles, ou recherches botaniques et géologiques sur les Végétaux renfermés dans les diverses couches du globe. $1-488$ pp.; 2-72 pp. Paris.

CHALONER, W.G. 1953. On the megaspores of four species of Lepidostrobus. Annals of Botany 17, 264-273.

Clendening, J.A. 1974. Palynological evidence for a Pennsylvanian age assignment of the Dunkard Group in the Appalachian Basin. Part II. West Virginia Geological and Economical Survey Coal Geology Bulletin 3, 1-75.

CLENDENING, J.A. 1975. Palynological evidence for placement of the Pennsylvanian-Permian boundary in Kansas, U.S.A. Permian Exploration Boundary, Stratigraphic Symposium SEPM, Midland, Texas 75, 91-97.

DetTManN, M.E. 1963. Upper Mesozoic microfloras from southeastern Australia. Proceedings of Royal Society of Victoria 77, $1-148$. 
DIJKSTRA, S.J. 1955. Carboniferous megaspores of some Spanish basins and their use in corellation. Estudios Geológicos 11, 277-354.

DIJKSTRA, S.J. 1958. On a megaspore-bearing lycopod strobilus. Acta Botanica Neerlandica 7, 217-222.

Dimichele, W.A. \& BATEMAN, R.M. 1996. The rhizomorphic lycopsids: a case study in paleobotanical classification. Systematic Botany 21, 535-552. DOI 10.2307/2419613

DYBovÁ-JACHOWICZ, S., JACHOWICZ, A., KARCZEWSKA, J., LachKar, G., Loboziak, S., Piérart, P., Turnau, E. \& ŽOLDANI, Z. 1979. Note préliminaire sur la révision des megaspores à gula du Carbonifère. Les principles de la classification. Acta Paleontologica Polonica 24(4), 411-422.

DyBova-JaCHOWICZ, S., JACHOWICZ, A., KARCZEWSKA, J., LachKar, G., LoboziaK, S., PiÉrart, P., Turnau, E. \& ŽOLDANI, Z. 1987. Revision of Carboniferous megaspores with gula (Part three). Prace Institutu geologicznego 121, 49.

FENG, Z., WANG, J. \& BEK, J. 2008. Nudasporestrobus ningxicus gen. et sp. nov., a novel sigillarian megasporangiate cone from the Bashkirian (Early Pennsylvanian) of Ningxia, northwestern China. Review of Palaeobotany and Palynology 149, 150-162. DOI 10.1016/j.revpalbo.2007.11.003

GERMAR, E.F. 1851. Die Versteinerungen des Steinkohlengebirges von Wettin und Lebejün in Saalkreise. C.A. Schwetschke und Sohn, Halle.

HEMSLEY, A.R. \& GALTIER, J. 1992. On the exine of Sublagenicula nuda (Nowak et Zerndt) Dybova-Jachowicz et al. Palaeovegetational development in Europe. Proceedings of the Pan-European Paleobotanical Conference, Vienna, 363-369.

JACHOWICZ, A. 1966. Mikroflora warstw Zarębianskich z gór Świętokrzyskich. Institut Geologiczny Prace 49, 1-108.

KALIBOVÁ, M. 1951. Megaspory radnického slojového pásma kladenskorakovnické kamenouhelné pánve. Sborník Ústředního ústavu geologického, Palaeontologie 18, 21-92.

KalibovÁ, M. 1963. A Carboniferous sporae dispersae in the Očelice boring in Eastern Bohemia. Věstník Ústředního ústavu geologického 38, 179-181.

KALIBOVA, M. 1964. Megasporenforschung im gebiet zwischen Všeruby, Horní Bělá, Horní Bříza und Chotíkov im Nördlichen teil des Pilsner-steinkohlenbeckens. Časopis pro mineralogii a geologii 8(2), 151-157.

KALIBOVÁ-KAISEROVÁ, M. 1972. Distribution of stratigraphically significant miospores in the Central Bohemian Carboniferous Complex. Compte rendu du Septième Congrès International de Stratigraphie et de Géologie du Carbonifère, Krefeld, August 1971, 38

KALIBOVÁ-KAISEROVÁ, M. 1978. Palynology of the Jelenice member (Stephanian). Sborník geologických věd, Paleontologie 20, 63-135.

KosANKE, R.M. 1950. Pennsylvanian spores of Illinois and their use for correlation. Bulletin of Illinois State Geological Survey $74,1-128$.

NAUGOLNYKH, S.V. \& ORLOVA, O.A. 2006. Moscvostrobus - a new genus of Carboniferous lycopods from the Moscow Region (Russia). The Palaeobotanist 55, 1-14.

NOWAK, J. \& ZERNDT, J. 1936. Zur Tektonik des Östlichsten Teils des Polonischen Steinkohlenbeckens. Bulletin International de l'Académie Polonaise des Sciences et des lettres, Série A, $56-73$.

OSHURKOVA, M.B. 2001. Carboniferous megaspores. Systematics, biostratigraphical significance. 112 pp. VSEGEI Press, St. Petersburg. [in Russian with English diagnoses]

PEPPERS, R.A. 1964. Spores in strata of Late Pennsylvanian cyclothems in the Illinois Basin. Bulletin of Illinois State Geological Survey 90, 1-72.

PEŠEK, J. 1994. Carboniferous of central and western Bohemia (Czech Republic). 48 pp. Czech Geological Survey, Prague.

PIÉRART, P. 1956. Quelques mégaspores contenues dans les charbons stéphaniens des bassins de Blancy et de Decazeville. Bulletin de la Société belge de Géologie, Paléontology et d'Hydrologie 64(3), 585-599.

PIÉRART, P. 1961. Les megaspores du houiller de Kaiping (Chine). Mededeelingen van de Geologische Stichting, Nieuwe Serie 13, $39-44$.

PIÉRART, P. 1965. Mégaspores du Stéphanien français. Mededeelingen van de Geologische Stichting, Nieuwe Serie 17, 28-30.

POTONIÉ, R. \& KREMP, G. 1954. Die Gattungen der Palaözoischen Sporae dispersae und ihre Stratigraphie. Geologische Jahrbuch 69, 111-193.

Potonié, R. \& KRemp, G. 1955. Die Sporae dispersae des Ruhrkarbons ihre Morphographie und Stratigraphie mit Ausblicken auf Arten anderer Gebiete und Zeitabschnitte. Teil I. Palaeontographica B 98, 1-136.

Punt, W., Hoen, P.P., Blackmore, S., Nilsson, S. \& Le THOMAS, A. 2007. Glossary of pollen and spore terminology. Review of Palaeobotany and Palynolynology 143, 1-81.

DO1 10.1016/j.revpalbo.2006.06.008

RENAULT, M.B. 1888. Notice sur les Sigillaires. Bulletin de la Société d'historie naturelle d'Autun 1, 177.

SMith, A.H.V. \& BUTTERWORTH, M.A. 1967. Miospores in the coal seams of the Carboniferous of Great Britain. Special Papers in Palaeontology 1, 1-324.

TÁSLER, R., ČADKOVÁ, Z., DVOŘÁK, J., FEDIUK, F., CHALOUPSKÝ, J., JETEL, J., KAISEROVÁ, M., PROUZA, V., SCHOVÁNKOVÁ, D., STŘEDA, J., STŘíDA, M. \& ŠETLÍK, J. 1979. Geology of the Bohemian part of the Intra-Sudetic Basin. 292 pp. Ústřední ústav geologický, Praha. [in Czech with English summary]

TAYLOR, W.A. 1990. Comparative analysis of megaspore ultrastructure in Pennsylvanian lycophytes. Review of Palaeobotany and Palynology 62, 65-78.

DOI 10.1016/0034-6667(90)90017-D

THOMAS, B.A. \& DYTKO, A. 1980. Lepidostrobus haslingdenensis: a new species from the Lancashire Millstone Grit. Geological Journal 15, 137-142.

VALTEROVÁ, P. 1979. Paleopalynologicko-stratigrafický výzkum českého kř́lla vnitrosudetské pánve. Ph.D. thesis, Charles University, Prague, Czech Republic.

VenKatAChALA, S. \& BHARADWAJ, D.C. 1964. Sporological study of the coals from Falkenberg (Faulquemont) Colliery, Lothringen (Lorrain), France. Palaeobotanist 11, 159-207.

WINSLOW, M.R. 1959. Upper Mississipian and Pennsylvanian megaspores and other plant microfossils from Illinois. Illinois State Geological Survey Bulletin 86, Pl. I-XVI.

ZEILLER, R. 1906. Etude sur la flore fossile du bassin houiller de Blanzy et du Creusot. Études des gîtes minéraux de la France, $1-261$.

ZERNDT, J. 1937. Megaspory z westfalu i stefanu w Czechach. Megasporen aus dem Westfal und Stefan in Böhmen. Bulletin International de l'Académie polonaise des Sciences et des Lettres, série A 9-10A, 583-599. 